IZA DP No. 4834

Excess Leverage and Productivity Growth in

Emerging Economies: Is There A Threshold Effect?

Fabrizio Coricelli

Nigel Driffield

Sarmistha Pal

Isabelle Roland

March 2010 


\title{
Excess Leverage and Productivity Growth in Emerging Economies: Is There A Threshold Effect?
}

\author{
Fabrizio Coricelli \\ Paris School of Economics and CEPR \\ Nigel Driffield \\ Aston Business School \\ Sarmistha Pal \\ Brunel University and IZA \\ Isabelle Roland \\ London School of Economics
}

Discussion Paper No. 4834
March 2010

IZA

P.O. Box 7240

53072 Bonn

Germany

Phone: +49-228-3894-0

Fax: +49-228-3894-180

E-mail: iza@iza.org

\begin{abstract}
Any opinions expressed here are those of the author(s) and not those of IZA. Research published in this series may include views on policy, but the institute itself takes no institutional policy positions.

The Institute for the Study of Labor (IZA) in Bonn is a local and virtual international research center and a place of communication between science, politics and business. IZA is an independent nonprofit organization supported by Deutsche Post Foundation. The center is associated with the University of Bonn and offers a stimulating research environment through its international network, workshops and conferences, data service, project support, research visits and doctoral program. IZA engages in (i) original and internationally competitive research in all fields of labor economics, (ii) development of policy concepts, and (iii) dissemination of research results and concepts to the interested public.
\end{abstract}

IZA Discussion Papers often represent preliminary work and are circulated to encourage discussion. Citation of such a paper should account for its provisional character. A revised version may be available directly from the author. 
IZA Discussion Paper No. 4834

March 2010

\section{ABSTRACT \\ Excess Leverage and Productivity Growth in Emerging Economies: Is There A Threshold Effect?*}

The paper examines the relationship between leverage and growth in a group of emerging central and eastern European countries, who are at different levels of financial market development. We hypothesize a non-linear relationship in that moderate leverage could boost growth while very high leverage could lower it by increasing the likelihood of financial distress and bankruptcy. Estimates of a Threshold model confirm the non-linear relationship in our sample, after controlling for various firm, industry and financial market characteristics. We also endogenously determine a threshold level of leverage beyond which further increases in leverage could lower TFP growth.

JEL Classification: $\quad$ G32, O16

Keywords: excess leverage, bank efficiency, market capitalization, TFP growth, Threshold model, non-linear relationship, transition experience

Corresponding author:

Sarmistha Pal

CEDI, Department of Economics and Finance

Brunel University

Uxbridge UB8 3PH

United Kingdom

E-mail: sarmistha.pal@brunel.ac.uk

\footnotetext{
* Sarmistha Pal is grateful to Erik Berglof and his staff at EBRD for hospitality during the initial work on the paper. Financial support from ESRC grant RES-062-23-0986 is gratefully acknowledged. We are much grateful to an anonymous referee and the Managing Editor of this journal for very constructive suggestions and also to Stijn Claessens for FSDI data, Michael Landesman for the sectoral Price deflator data and Sourafel Girma and Michael Henry for assistance with the estimation of the threshold model. We thank Yama Temouri for research assitance and seminar participants at Aston Business School, UCL, EBRD and CICM conference London for comments and suggestions. The usual disclaimer applies.
} 


\section{Excess Leverage and Productivity Growth in Emerging Economies: Is There A Threshold Effect?}

\section{Introduction}

Economists have long recognized that financial conditions in the private sector could have a powerful effect on macroeconomic outcomes. Increases in leverage can lead to greater probability of default, and in turn higher costs of external financing. This could lower investment, cash flow and therefore output (Kyotaki and Moore, 1997). Increases in corporate leverage could also induce severe slowdowns by amplifying/propagating initial adverse shocks (e.g., demand) on the real economy (Bernanke and Gertler, 1995). Despite the importance of this question, especially in the current economic climate, we are not aware of any study that explores the link between corporate leverage and the wider economy which we propose.

Corporate leverage decisions are among the most important decisions made by firm executives. The current economic crisis has however highlighted the risks of global boom-bust cycles driven by lending, which in turn raises the need to understand the link between leverage decisions and the wider economy. Since Modigliani and Miller (1958), research has focused on understanding/analysing corporate financial choices and policies around the world, especially in the US. This literature highlights the firm, market and industry characteristics determining optimal leverage and also its dynamic adjustment process in case of a departure from the optimal (e.g., Driffield and Pal, 2010). A parallel literature on financial institutions has also paid attention to different aspects of problem loans and cost inefficiency (e.g., see Berger and Humphrey 1992; Bonin et al. 2005). While there is limited literature on the relationship between leverage and firm value/performance (e.g., McConnell and Servaes, 1995; Berger and di Patti 2006; 
Driffield, Mahambare and Pal, 2007), there is very little, if at all, understanding as to how departure from optimal leverage could affect productivity growth, especially for emerging economies with weak financial institutions.

In an attempt to bridge this gap in the literature we argue that higher leverage may reduce the agency costs of outside equity, and increase firm value (and efficiency) by encouraging managers to act more in the interests of shareholders (McConnell and Servaes, 1995). ${ }^{1}$ Thus, higher leverage is likely to be associated with higher total factor productivity (TFP) growth. We also highlight the non-linear aspect of this relationship: while moderate leverage could undoubtedly boost TFP and therefore the level of output, very high leverage may be responsible for an economy's vulnerability to unexpected shortfalls in demand and mistakes. This is because excessive leverage could create excess capacity and lead to financial distress and even bankruptcy in response to adverse shocks (Greenspan, 2002). Given that the sample countries are at different stages of financial market development, the likelihood of excess leverage and also its effect on TFP growth may vary across the sample countries, even after controlling for various firm and industry level characteristics. These are open empirical questions that we explore in the paper.

The analysis is based primarily (see section 2) on firm-level Orbis data from a group of central and eastern European (CEE) transition countries. This sample is interesting for several reasons. Even after more than a decade of reform, there is a growing feeling that the reforms have failed to spur adequately the development of corporate financing opportunities in the central and eastern European (CEE) countries. Unlike much of the literature for developed countries (e.g., see Fischer, et al, 1989; Goldstein, Ju and Leland 2001; Strebulaev 2007), the literature on capital structure for developing and transition countries has highlighted the importance of

\footnotetext{
${ }^{1}$ There can also be reverse causation. For example, more efficient firms may choose lower equity ratios (i.e., higher debt) than others, all else equal, because higher efficiency reduces the expected costs of financial distress and bankruptcy (Berger and di Patti, 2006). See further discussion in section 3.
} 
excess leverage (e.g., see Driffield and Pal, 2010). An important aspect of our analysis has been to take account of the nature of financial markets development in the sample because weaknesses in financial sector operations and management have been a major factor contributing to the current financial crisis across the globe. Our analysis in this respect has been facilitated by the availability of the Financial Sector Development Indicators or FSDI for short (see World Bank 2006). ${ }^{2}$ Among various available indices, we particularly focus on banking efficiency and share of market capital to gross domestic product, both of which tend to play an important role in our analysis (see further discussion in section 2.4).

Following the well-developed literature on corporate leverage and its dynamic adjustment (e.g., see Booth et al. 2001; Flannery and Rangan, 2006), we start our analysis with the conventional approach of identifying firms with leverage in excess of its optimal level (instrumented by the fitted values of leverage). This analysis highlights the incidence of excess leverage among sample firms with access to loans and also that the indices of financial market development, namely, low bank efficiency and limited market capitalization significantly contribute to the likelihood of excess leverage, after controlling for other firm and industry-level factors. Note, however, that the conventional regression method does not allow us to endogenously determine the particular leverage level that may harm total factor productivity growth. Therefore, we follow Hansen (2000) to endogenously determine a threshold level of leverage beyond which leverage has an adverse effect on productivity growth. Indeed, there is some evidence from the threshold analysis that TFP growth increases with leverage only up to a certain point. However, beyond a critical level, greater leverage lowers TFP growth, even after controlling for various firm-level and institutional characteristics. Results of our analysis also highlight the beneficial role of greater financial market development, as signified by the positive effects of greater

\footnotetext{
${ }^{2}$ See further discussion in section 2.
} 
bank efficiency and market capitalization on TFP growth. These results hold irrespective of the choice of leverage measures and also various sub-samples.

A better understanding of the causes and implications of capital structure imbalances for TFP growth is important, especially in the wake of the current credit crunch and the subsequent turmoil in many countries around the globe. Results of our analysis may provide important insights into the problem and also implications for future deleveraging policies. Our analysis has already been adapted in the Transition Report (see EBRD 2009, P. 69-70), highlighting its relevance for policy makers.

The analysis is developed in stages. Section 2 describes the data while section 3 explains the threshold model and the empirical analysis. Section 4 concludes.

\section{Data Description}

Data used for the analysis is primarily taken from Orbis, a rich firm-level dataset, which is provided by Bureau van Dijk electronic publishing. Firm-level Orbis data has been supplemented by country-level data obtained from the EBRD and the World Bank. The World Bank (2006) has developed a range of indices to measure size, efficiency and stability of the banking sector as well as the equity markets for a cross section of countries, including the countries of our interest, for the period 20012005. These are commonly known as the Financial Services Development Indices or FSDI in short.

Our sample consists of manufacturing firms from twelve transition countries, namely, Bulgaria, Croatia, Czech Republic, Hungary, Latvia, Poland, Romania, Russia, Serbia, Slovakia, Slovenia and Ukraine over the period 2001-2005. Choice of the sample period has been dictated by the fact that FSDI data is available only for this period. This has been a period of steady growth of domestic credit (as a share of 
GDP) in the region, which stabilized around 2005 for most of the sample countries (see Figure 1). The total number of observations for the period 2001-2005 is summarized in Table 1 for each sample country.

\subsection{Leverage measures}

We use different measures of leverage, generally dictated by the availability of relevant information. First, we use the ratio of total debt (short and long-term debt) to total assets (abbreviated as TDTA). As an alternative, we use the ratio of total liabilities to total assets (abbreviated as TLTA), which is available for a larger proportion of sample firms. Note however that a large proportion of firms do not use any debt finance; thus the sample size is smaller when we use TDTA. While we do not observe market value of equity, there is information on book value of equity; there are however many missing observations, thus rendering the use of this rather problematic.

Table 1 shows the average leverages between 2001 and 2005 for twelve sample countries, using the leverage measures described above for all firms and also for non-zero debt firms. There are some firms in each of these sample countries for which no information on debt was available. Further, given limited use of external finance in CEE countries, there is a significant proportion of firms with zero debt in our sample, ${ }^{3}$ notably in Romania. This reflects the fact that many firms still do not have access to debt markets in these economies and instead make heavy use of internal finance, trade credit and other kinds of liabilities.

Among all firms, the average ratio of total liabilities to total assets ranges between 0.34 (Slovenia) and 0.60 (Slovakia). The range for average debt ratio is however much narrower, namely between 0.02 (Romania) and 0.19 (Czech

\footnotetext{
${ }^{3}$ Note also that there are a number of cases when there was very little data for total debt in the sample countries, especially, Croatia and Slovenia (see Table 1).
} 
Republic). Since a significant proportion of firms in each of these countries do not have access to any debt, it may be pertinent to focus on indebted firms (i.e., those with some non-zero debt) only. The average debt ratio goes up somewhat when we consider the subsample of firms with non-zero debt. So we need to be cautious about choosing between samples (all firms versus non-zero debt firms) while analyzing/interpreting debt ratios. ${ }^{4}$

Table 2 shows debt ratio percentiles and the distribution of average debt ratios by firm size (proxied by total assets). Clearly, the debt ratios of firms in the lowest quartile are significantly lower from those in the top $5-10 \%$ of the distribution in most sample countries. In fact the debt ratio exceeds 1 for the top $1 \%$ firms in Bulgaria, the Czech Republic and Russia. While a large proportion of firms in the sample countries are deprived of loans, there is evidence that some firms tend to have access to too much loans. Second, while the larger firms tend to have higher leverage in Bulgaria, Croatia, the Czech Republic, Romania, Serbia, Slovakia, the opposite holds for the other sample countries. The correlation between firm size (measured by $\log$ of total assets) and leverage, as shown in Table 2, suggests a significant positive correlation for Croatia, Serbia and Slovakia while it is significantly negative for Poland, Russia and Ukraine; the correlation coefficient however remains insignificant for other sample countries.

\subsection{Optimal leverage}

In an attempt to understand the nature and extent of excess leverage, if any, we start with the conventional literature (e.g., see Flannery and Rangan, 2006; Driffield and Pal 2010) to determine the optimal leverage $\mathrm{L}_{\mathrm{it}}{ }^{*}$ (alternatively labeled as capital structure) of firms in individual countries. This allows us to have an estimate of the

\footnotetext{
${ }^{4}$ We have also experimented with alternative leverage measures, namely, debt and liability ratio net of cash-flow, which yielded rather comparable results to those presented here.
} 
leverage gap, i.e., the deviation of actual leverage from its optimal level (see section 2.3).

If leverage levels are relatively stable over time, then a simple average of the fitted values for each firm across time may provide the best estimate of optimal leverage. However, if the data are more volatile (as in our case), and firms are responding to changes in the explanatory variables, or to other shocks (e.g., ongoing reforms), then allowing the optimal level to vary year to year, and using the fitted values on an annual basis is more appropriate, and this is what we do. Once one allows for this, the best estimate of "optimal leverage" is conventionally taken to be the fitted value ${ }^{5}$ derived from the following equation estimated individually for each country:

Leverage $_{i t}=\beta_{0}+\beta_{1} \log (\text { assets })_{i t-1}+\beta_{2}$ Age $_{i t-1}+\beta_{3}$ (fixed assets $/$ total

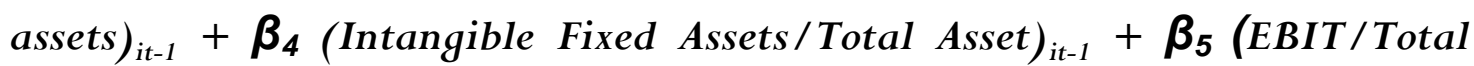
Assets) $)_{i t-1}+\beta_{6}$ (shareholder's funds/total asset) $_{i t-1}+\beta_{7}$ (growth of total assets $_{i t-1}+\beta_{8}$ inflation $_{i t-1}+\beta_{9}$ Industry Median Leverage $_{t-1}+v_{i}+u_{i t}(1)^{6}$

where $\mathrm{i}=1,2, \ldots, \mathrm{N}$ refers to the $\mathrm{i}$-th firm in period $\mathrm{t}=1,2, \ldots, \mathrm{T}$ in a given country $\boldsymbol{v}_{\boldsymbol{i}}$ is the firm-specific fixed effects while $\boldsymbol{u}_{i t}$ refers to random errors independently and identically distributed. Definitions of these variables are provided in a note to Table 5. We use panel data fixed effects models to estimate the leverage equation (1), using both debt and liability ratios as alternative measures of leverage. Choice of fixed effects as opposed to random effects has been dictated by the sample data. Choice of the explanatory variables has been guided by the existing literature (e.g., see Rajan and Zingales, 1995; Flannery and Rangan, 2006; Frank and Goyal, 2009; Driffield and Pal 2010) and also data availability; e.g., we were unable to calculate

\footnotetext{
${ }^{5}$ Later in the paper, we endogenously determine the optimal leverage, using a threshold model.

${ }^{6}$ EBIT is the earnings before interest and taxes.
} 
market to book ratio and therefore replace it by shareholders' funds as a share of total assets. All the explanatory variables are lagged by one period. We experiment with various specifications and show the estimates of debt and liability ratios for the best fitted models in Appendix Table A1. ${ }^{7}$

Clearly these estimates are somewhat different for debt and liability ratios and inter-country variation is also pronounced in these estimates. In general, firm size, intangible fixed assets, profitability and shareholders' funds tend to be generally significant, although the size and sign of these coefficients vary.

\subsection{Deviation from optimal leverage}

We estimate equation (1) country by country and use the predicted values of leverage ratios as the optimal target leverage $\mathrm{L}_{\mathrm{it}}{ }^{*}$ of the $\mathrm{i}$-th firm in year $\mathrm{t}$. Estimation of the optimal leverage $\mathrm{L}_{\mathrm{it}}{ }^{*}$ allows us to compute the deviation of the actual leverage from the corresponding optimal as $\left(\mathrm{L}_{\mathrm{it}} \mathrm{L}_{\mathrm{it}}{ }^{*}\right)$. In order to understand the pattern of imbalance in corporate leverage, we distinguish between firms with a leverage deficit (i.e., for which the actual debt or liability ratio is less than their corresponding target) and those with excess leverage (i.e., for which the actual debt or liability ratio exceeds the corresponding optimal level). No sample firm had exactly the optimal leverage (debt or liability). Accordingly, we construct the following binary variable: EXCESS $_{\text {it }}=1$ if the $\mathrm{i}$-th firm has excess leverage in year $\mathrm{t}$.

$=0$ if the $\mathrm{i}$-th firm has a leverage deficit in year $\mathrm{t}$ (since no firm has optimal leverage in our sample)

Depending on the alternative measures of leverage, we generate two variables, namely, the "excess debt ratio" (EXCESSTD) and the "excess liability ratio"

\footnotetext{
${ }^{7}$ We also used alternative leverage indices, namely, net debt and net liability ratios, as discussed in section 2.1; we find that these alternative estimates are rather similar to the ones shown in Table A1. These estimates would be available on request.
} 
(EXCESSTL). Table 3 summarizes the proportion of firms with excess leverage and the corresponding average gap for firms with excess leverage. The analysis is done only for firms with some positive debt. Clearly a significant majority of firms in the sample countries tend to have excess leverage and this transition experience contrasts with much of the existing capital structure literature for developed countries (also see Driffield and Pal, 2010).

It is interesting to compare the frequency of firms with excess leverage in the sample CEE countries with those available for the East Asian Economies. Clearly, countries from east Asia (vis-a-vis more developed OECD countries) are more comparable to CEE countries: (i) bank-based finance dominates in both east Asia and CEE countries; (ii) indices of financial market developments are more comparable too. Clearly the proportions of firms with excess leverage for all the CEE sample countries are higher than those for the east Asian countries (see Appendix Table A2) studied by Driffield and Pal (2010), thus inducing us to examine the factors determining the likelihood of excess leverage in the CEE region.

\subsection{Financial institutions and excess leverage}

Persistence of deviations from optimal leverage levels highlights the aspects of capital market imperfections, which may prevent an instantaneous adjustment of the actual leverage to the desired level (for example, see Fisher Heinkel and Zechner, 1989; Goldstein, Ju and Leland, 2001; Strebulaev, 2007). While much of the transition literature focuses on firm-level characteristics in understanding capital structure dynamics, we argue that persistence of excess leverage could be a sign of regulatory weaknesses in debt issuance, management and recovery. Even allowing for the fact that a high proportion of firms in the sample countries do not have any bank loans, it is perhaps surprising to find that the incidence of excess leverage among non-zero 
debt firms in many CEE countries is higher than those in the worst affected countries in East Asia (Driffield and Pal, 2010). Accordingly, we explore the role of financial institutional indices, ceteris paribus, on the presence of excess leverage in the sample countries.

Table 4 summarizes the average characteristics of available financial and legal indices in the region, prepared using information from the EBRD, the World Bank FSDI indices and la Porta et al. (1998). Among others, the Table includes measures of size, efficiency and stability of the banking sector (available from World Bank), market capitalization to GDP, share of foreign banks (available from EBRD), and the quality of creditors' rights (available from la Porta et al. ,1998). Share of market capitalization to GDP is generally limited in most of the sample countries, especially, in Bulgaria, Latvia, Slovakia and Serbia. Firms' external financing opportunities thus depend crucially on the size and efficiency of the banking sector though the experience varies widely among the sample countries. In particular, Romania not only have the smallest banking sector, but efficiency of the banking sector is also the lowest in our sample. It is however noteworthy that compared to Romania, scores for average creditors' rights are much higher in Serbia or Ukraine, which may facilitate the growth of banking sector. The other important observation relates to the predominance of foreign banks in countries like Poland, Romania or Hungary as opposed to Serbia, Slovenia, Ukraine or Russia.

Table 5 summarizes the mean comparison of selected characteristics including firm size (log of total assets), age, foreign ownership, fixed assets, intangible fixed assets, earnings ratio (index of profitability), and the rate of CPI inflation. We also include some characteristics of financial institutions in our analysis on the ground that weaknesses in financial sector have been closely linked to the current financial and economic crisis. Note however that these financial institutional indices are closely correlated; our analysis thus includes measures of bank efficiency and market 
capitalization (as a share of GDP), as these indices have highest correlations with measures of excess leverage. On average, smaller firms (by total assets), younger firms and firms with more fixed assets are significantly more likely to have excess leverage. Firms from countries with higher inflation are also more likely to have excess leverage. In terms of financial institutions, sample firms are significantly more likely to have excess leverage, on average, if they come from countries with lower bank efficiency, lower market capitalization rate.

Finally, we estimate a conditional fixed effects logit model to formally determine the likelihood of having excess leverage (EXCESSTD and EXCESSTL) in terms of various firm, industry and country level characteristics in our sample. We choose fixed rather than random effects model to determine the likelihood of excess leverage because the former reduces the potential endogeneity bias arising from unobserved firm-specific heterogeneity in the data. Among the firm-level characteristics, we include firm size (log of total assets), age (in years), share of fixed assets in total assets (FATA), share of intangible assets in total assets (IFATA) and profitability (EBIT as a share of total assets). In addition, we include country inflation rate, efficiency of the banking sector (BANKEFF) and also the ratio of market capitalization to GDP (MKTGDP) to control for country-level variations in these respects. Table 6 shows the conditional fixed effects logit estimates of excess debt (EXCESSTD) and excess liability (EXCESSTL) ratios for the pooled panel data. Naturally, the time invariant variables are dropped from the logit fixed effects estimates. Two sets of estimates are shown here and these estimates correspond to the choice of sample: (a) all firms and (b) non-zero debt firms. In line with Table 5, these estimates establish the significant role of institutions on the presence and persistence of excess leverage, after controlling for other covariates, in our sample. While greater inflation enhances the probability of excess leverage, higher efficiency of the banking sector and higher market capitalization to GDP are generally 
associated with a lower probability of firms having excess leverage (note however that the effect of market capitalization is insignificant in determining EXCESSTD among non-zero debt firms). Clearly, a more efficient banking sector is able to screen out bad loans while a greater degree of market capitalization not only offers an alternative source of external finance, but could also contribute to improved corporate governance practices. There is thus evidence that the incidence of excess leverage among sample firms is linked to weaker financial institutions in our sample of CEE countries.

\section{Implications of Excess Leverage for TFP Growth}

The analysis so far has shown that while access to loans is limited for a significant proportion of firms in our sample, excess leverage is common among firms with some positive loans. It has also been established that the presence and persistence of excess leverage among sample firms is closely related to the quality of financial markets and institutions. The final task in this paper is to examine the effect of excess leverage, if any, on firm performance measured by total factor productivity (TFP) growth. Our central hypothesis is that while moderate levels of debt can stimulate TFP growth, through providing finance for new technology, innovation or new capacity, after a given threshold, this debt becomes a drag on performance, as the firm has to focus on cash flow in order to service the debt, rather than continued improvements in productivity. As discussed above, firms with excess debt are extremely vulnerable to unexpected adverse demand shocks.

In order to test this hypothesis one could possibly use a fixed-effects model to regress total factor productivity growth on excess leverage and its non-linear terms, after controlling for other covariates. But this may raise questions, especially because the conventional method does not allow us to endogenously determine the particular 
leverage level that may harm total factor productivity growth. All we could do is to experiment with different leverage levels and try to identify some leverage that could harm productivity growth. Accordingly, we employ the threshold regression analysis of Hansen (2004) to the data. This identifies the threshold levels of leverage beyond which further increases in leverage could lower total factor productivity growth. We begin by examining this in the aggregate, and subsequently move on to some comparisons across countries, and across different types of firms.

\section{Leverage and Total Factor Productivity}

Estimates of TFP are generated using the well understood Levinsohn-Petrin method (a la Levinsohn and Petrin, 2003). Given that we were able to find industry-level price deflators for only 9 out of 12 of the sample countries, this TFP measure could be constructed for these 9 countries only, thus excluding firms from Croatia, Romania and Serbia from our original sample analyzed in section 2.

Figure 2 plots average TFP growth for these nine countries during 20012005. Clearly, TFP growth rate has been rather stable in most countries with the exception of Hungary and Slovenia during the sample period 2001-2005.

\subsection{An Endogenous Threshold Model}

The threshold model is particularly relevant to test our central hypothesis, as it endogenously determines the existence and significance of one or more leverage thresholds (and the corresponding confidence intervals), which in turn allows us to assess the growth effects of leverage as a nonlinear process. Depending on whether the leverage is less than, equal to or greater than the threshold, we could obtain marginal effects associated with different bands of leverage in the model and also test whether the marginal effects are significantly different. 
Let us start with the simplest threshold model for total factor productivity growth of the $\mathrm{i}$-th firm for the period $[\mathrm{t}, \mathrm{t}+1]$ as follows:

$$
\begin{aligned}
& \Delta \mathrm{TFP}_{\mathrm{it}+1}=\alpha_{1} \mathrm{~L}_{\mathrm{it}}+\beta^{\prime} \mathrm{X}_{\mathrm{it}}+v_{\mathrm{it}} \text { if } \mathrm{L}_{\mathrm{it}} \leq \gamma \\
& \Delta \mathrm{TFP}_{\mathrm{it}+1}=\alpha_{2} \mathrm{~L}_{\mathrm{it}}+\beta^{\prime} \mathrm{X}_{\mathrm{it}}+v_{\mathrm{it}} \text { if } \mathrm{L}_{\mathrm{it}}>\gamma
\end{aligned}
$$

Combining (3a) and (3b), we could write:

$$
\left.\Delta \mathrm{TFP}_{\mathrm{it}+1}=\beta^{\prime} \mathrm{X}_{\mathrm{it}}+\alpha_{1} \mathrm{~L}_{\mathrm{it}} \mathrm{I}_{(\mathrm{it}} \leq \gamma\right)+\alpha_{2} \mathrm{~L}_{\mathrm{it}} \mathrm{I}\left(\mathrm{L}_{\mathrm{it}}>\gamma\right)+v_{\mathrm{it}}
$$

where $\mathrm{L}_{\mathrm{it}}$ is the initial value of leverage (i.e., debt or liability ratio). I(.) represents an indicator function, indicating whether leverage measure of the $\mathrm{i}$-th firm at time $\mathrm{t}$ is less than equal to or greater than a threshold parameter $\gamma ; \gamma$ is the endogenous threshold value to be estimated from the model (please see discussion in section below). The errors $v_{\text {it }}$ are assumed to be independent and identically distributed with mean zero and finite variance. Depending on whether the actual leverage is smaller/equal to or larger than the threshold value $(\gamma)$ to be estimated, observations are divided into two "regimes" where the regimes are distinguished by differing regression slopes, $\alpha_{1}$ and $\alpha_{2}$.

Let $S_{n}(\beta, \alpha(\gamma))$ represent the sum of squared errors for equation (4), where $n$ is the sample size. Given that the parameters $\alpha$ depend on the threshold parameters $\gamma$, we denote them by $\alpha(\gamma))$. Because of this dependence, S(.) is not linear in the parameters but rather a step function where steps appear at some distinct values of the threshold variable $\gamma$. But conditional on a given threshold value, say $\gamma=\gamma_{0}, \mathrm{~S}($.) is linear in $\beta$ and $\alpha$. Accordingly, $S\left(\beta, \alpha\left(\gamma_{0}\right)\right)$ can be minimised to yield the conditional OLS estimates $\beta^{\wedge}\left(\gamma_{0}\right)$ and $\alpha^{\wedge}\left(\gamma_{0}\right)$. Among all possible leverage values, the estimate of the threshold corresponds to that value of $\alpha$, which minimises the sum of squared errors $\mathrm{S}\left(\beta, \alpha\left(\gamma_{0}\right)\right)$ for $\gamma=\gamma_{0}$. Following Girma (2005), this minimisation problem is solved by a grid search over 393 leverage quantiles $\{1.00 \%$, 
$1.25 \%, 1.50 \%, \ldots, 98.75 \%, 99 \%\}$. Once the sample splitting value of $\gamma$ is identified, the estimates of the slope parameters are readily available.

If a threshold effect is identified, i.e.., $\alpha_{1} \neq \alpha_{2}$, it is important to form a confidence interval for the particular threshold value $\gamma$ in this context. This necessitates us to test the following null hypothesis:

$$
\text { Ho : } \gamma=\gamma_{0}
$$

Under normality, the likelihood ratio (LR) test statistic is routinely used in standard econometric applications to test for particular parametric values. But Hansen (2000) shows that $\operatorname{LRn}(\gamma)$ does not have a standard chi-square distribution in the threshold model. The correct distribution function and the appropriate asymptotic critical values need to be obtained from the bootstrapped standard errors (see Girma 2005 for further details).

Suppose that the two confidence limits of the threshold $\gamma$ are given respectively by $\gamma_{1}$ (lower) and $\gamma_{2}$ (upper). This allows us to define three sets of leverage variables as follows. Using debt ratio (TDTA) as the particular leverage measure, we generate tdta- (i.e., $\left.\operatorname{tdta} \leq \gamma_{1}\right), \operatorname{tdta}=\left(\right.$ i.e., $\left.\gamma_{1}<\operatorname{tdta} \leq \gamma_{2}\right)$ and tdta + (i.e., tdta $>\gamma_{2}$ ); similarly using the liability ratio as an alternative leverage measure, we generate tlta- (i.e., tlta $\leq \gamma_{1}$ ), tlta $=$ (i.e., $\gamma_{1}<\operatorname{tlta} \leq \gamma_{2}$ ) and tlta + (i.e., tlta $>\gamma_{2}$ ). Accordingly, equation (4) is modified as follows:

$$
\left.\Delta \mathrm{TFP}_{\mathrm{it}+1}=\alpha_{1} \mathrm{~L}_{\mathrm{it}} \mathrm{I}\left(\mathrm{L}_{\mathrm{it}} \leq \gamma 1\right)+\alpha_{2} \mathrm{~L}_{\mathrm{it}} \mathrm{I}\left(\gamma_{1}<\mathrm{L}_{\mathrm{it}} \leq \gamma_{2}\right)+\alpha_{3} \mathrm{~L}_{\mathrm{it}} \mathrm{I}_{\mathrm{it}}>\gamma_{2}\right)+\beta^{\prime} \mathrm{X}_{\mathrm{it}}+v_{\mathrm{it}}
$$

In addition to different bands of leverage as shown in equation (5), we include initial values of a number of other control variables $\mathrm{X}_{\mathrm{it}}$, namely, firm size (SME), age (Young), share of intangible assets (IFATA), ownership (foreign) and also some institutional characteristics, namely, efficiency of the banking sector and also the 
extent of market capitalization to GDP. ${ }^{8}$ This is because the extent to which debt will act to restrict productivity growth is expected to vary with the size/efficiency of the financial market. The more effective the market, the less likely moral hazard would lead to excess leverage, and the lower the level of debt the firms may accrue before the servicing the debt acts as a constraint. $\mathrm{X}_{\mathrm{it}-1}$ also includes the initial value of TFP as a control variable; significance of initial TFP will highlight the importance of Barro's conditional convergence hypothesis.

The final step in this estimation strategy is to establish the asymptotic distribution of the slope coefficients. Although these parameters depend on the estimated threshold limits $\gamma_{1}$ and $\gamma_{2}$, Hansen (2000) demonstrates that this dependence is not of first-order asymptotic importance. Consequently, the usual distribution theory (i.e. asymptotically normal) can be applied to the estimated slope coefficients so that one could use the asymptotic p-values to test whether there is a significant threshold effect, i.e., if $\alpha_{1}=\alpha_{2}=\alpha_{3}=0$; rejection of the null hypothesis would confirm the presence of a significant threshold effect. ${ }^{9}$

\subsection{Threshold estimates}

Threshold estimates for TFP growth are summarized in Table 7 and Table 8 for all firms and non-zero debt firms respectively. We first estimate the 95\% confidence interval for the threshold parameter $\gamma$. The confidence interval varies somewhat for debt and liability ratios while they tend to be robust irrespective of the choice of the sample (all firms versus non-zero debt firms).

Initial value of TFP is insignificant; thus there is no evidence of convergence in our sample. However all three leverage terms relating to different bands of the leverage thresholds are statistically significant and this holds irrespective of the choice

\footnotetext{
${ }^{8}$ See note to Table 6 for variable definitions.

${ }^{9}$ This procedure is explained in detail in Henry et al. (2003) and Girma (2005).
} 
of the leverage measure, debt or liability ratio. There is thus evidence that, after controlling for all other factors, moderate leverage (leverage $\left.\leq_{2}\right)$ could boost TFP growth, while excessive leverage (leverage $>\gamma_{2}$ ) lowers it. It is also evident that the marginal effect of an increase in leverage is significantly different for different bands of leverage and it decreases as we move from the lower leverage band to the higher one. In particular, these estimates suggest that a debt or liability ratio of around $40 \%$ or higher would lower TFP growth in our sample.

Among other results, the role of institutional factors is worth highlighting here. In particular, higher efficiency of the banking sector and higher market capitalization are both associated with higher TFP growth, thus confirming the beneficial role of institutions on long-run economic growth. The effect of intangible assets however turns out to be negative. While often intangible assets are taken to be a measure of $\mathrm{R} \& \mathrm{D}$, they also include overvalued goodwill and patents (which may correspond to the expected future value of intangible assets). Thus it is not unusual for intangible assets to have a negative effect on TFP growth.

Given the possibility of reverse causation (i.e., more efficient firms may choose lower equity ratios and hence higher debt than others), it is also important to test the robustness of our estimates for more/less efficient firms. In the absence of any better indicator, we consider profitability as an index of efficiency and classify firms according to (a) profit margin and (b) return on capital. In the light of our sample distribution, we consider two benchmark values for (a) and (b): (1) whether the firm has positive profit or rate of return on capital (ROCE) and (2) whether the firm has profit margin or ROCE in excess of the median values (which are about 0.04 for both these variables in our sample). Threshold estimates for non-zero debt firms for "profitable" and "non-profitable" firms are shown in Table 9. Naturally, the estimated threshold parameters are somewhat different, but they are well in line with 
the previous estimates for the pooled sample. As before, these estimates confirm the significant adverse effect of excessive leverage (beyond the upper threshold) on TFP growth in our sample. The contrast between profitable and non-profitable firms is also interesting. First, the upper threshold value of leverage is higher for more profitable firms. Second, the marginal adverse effects of excess leverage on TFP growth are also different between these two groups of firms. The absolute marginal effect of excessive leverage (beyond the upper threshold) is significantly higher for non-profitable firms, thus suggesting that effects of excess leverage are particularly bad for non-profitable firms.

Further robustness checks are done by splitting the sample by median firm size (defined by total assets) and median intangible assets ratio. In each case, we estimate the threshold model for firms in the upper half of the distribution of each of these variables. Threshold effects for each case are summarized in Appendix Table A3, which highlights the robustness of our results. The threshold estimates are quite stable across the various samples classified by firm size and intangible assets.

Finally, we use the leverage threshold estimates to calculate the percentage of firms above the upper threshold for each sample country. In this respect, we particularly focus on non-zero debt firms, distinguishing profitable firms (those with above median profit margin) from others. Results of our analysis are summarized in Table 10. Clearly, a significant proportion of all non-zero debt firms in many sample countries tend to have debt ratios in excess of the upper threshold limits; the proportion is significantly less when we consider more profitable non-zero debt firms. Furthermore, excess leverage is also common among non-profitable firms in most sample countries, with the exception of Slovenia. This is further highlighted in the pronounced inter-country variation: the proportion of firms with excessive leverage is zero in Slovenia while it is the highest in Russia. Results from our analysis thus highlight the aspect of inefficient allocation of credit and also its adverse effects 
on TFP growth, especially among non-profitable firms.

The upshot of our analysis is that unlike the conventional analysis one is able to endogenously determine the $95 \%$ confidence interval for the leverage threshold $\gamma$. This in turn allows us to test for the non-linearity in the relationship between leverage and TFP growth, if any. While moderate leverage could boost TFP growth, excessive leverage beyond the upper threshold limit would significantly lower TFP growth and this result is robust across various subsamples considered. The estimated upper leverage limit is about $40 \%$ irrespective of the leverage measure used. This is a significant finding, especially in an economic climate where excessive corporate leverage has been blamed for the current credit crunch. Our analysis allows the data to identify the safe threshold limit of leverage for the sample countries, which could guarantee significantly positive TFP growth. Our results have already been adapted in the Transition Report (EBRD 2009, p. 69-70), highlighting the relevance of the threshold model for policy making.

\subsection{Role of Financial Institutions}

Clearly the sample countries are heterogeneous in terms of efficiency of financial markets and institutions and, among various indices, our analysis has particularly highlighted the significant role of bank efficiency and market capitalization, not only on the likelihood of excess leverage (e.g., see Table 6), but also on total factor productivity growth (Tables 7-9). In order to explore the possible role of selected indices of financial institutions further, we now estimate the threshold model for individual countries, each characterized by given efficiency of financial institutions. Table 11 summarizes the threshold estimates for five of the nine sample countries namely Bulgaria, Poland, Russia, Serbia and Ukraine. We were unable to obtain estimates for the remaining countries, as the grid search process failed to identify the sample-splitting value of the threshold. We do not show the full set of estimates for 
brevity, but they are available on request.

Our central results remain unchanged in that moderate leverage continues to have a positive impact on TFP growth while high leverage (beyond the upper threshold limit) affects TFP growth negatively and the result holds for all five countries. Note, however, that the leverage thresholds tend to vary among these five countries: Serbia has the lowest $(0.288)$ while Russia has the highest $(0.514)$ leverage threshold in our sample. Given that these country-specific estimates are available only for 5 countries, it is hard to derive a definite relationship between financial institutions, as proxied by bank efficiency and market capitalization rate, and the estimated upper leverage threshold (above which TFP growth is affected negatively). As a rule of thumb, we calculate the correlation between the countryspecific threshold levels on the one hand and bank efficiency and market capitalization on the other for the 5 countries included in Table 11. While the correlation coefficients between bank efficiency and leverage threshold are negative (-0.15 and 0.26 respectively for debt ratio and liability ratio), those between market capitalization and the threshold level turn out to be positive $(0.85$ and 0.81 respectively for debt and liability ratios) for non-zero debt firms in our sample. These simple correlation coefficients perhaps highlight several, possibly conflicting, channels affecting the relationship between selected indices of financial markets and the estimated leverage threshold. ${ }^{10}$ In particular, upper leverage threshold is lower among firms from countries with greater bank efficiency, suggesting the beneficial role banks can play to screen and monitor good loans so as to avoid the kind of financial crisis that we experienced recently. We hope future research will shed further light in this respect.

\footnotetext{
${ }^{10}$ For example, greater market efficiency means that loans are channeled to the "right" firms, i.e. those with positive NPV projects that can sustain higher debt levels without running into difficulties (positive impact on upper threshold). In contrast, investors (be it banks or shareholders) in more efficient markets may start imposing discipline earlier, thus resulting in a negative impact on upper threshold (e.g., see 'Bad Management hypothesis' in Berger et al., 1997).
} 


\section{CONCLUSION}

The sizeable literature on capital structure and its dynamics in developed countries identifies the possible factors causing under-levering of firms and ways to adjust it. It is however common among firms in many developing and transition economies to maintain excess leverage though we know very little about the nature and implications of excess leverage for TFP growth. This paper is an attempt to bridge this gap in the literature, primarily using Orbis firm-level panel data from a group of CEE emerging economies. This allows us to understand the way corporate financial behavior could affect the wider economy.

We start with an analysis of excess leverage conventionally defined as the deviation of actual leverage from an optimal level derived from the fitted leverage values of a fixed-effects model. This analysis highlights that a significant proportion of firms do not have access to any bank loans while excess leverage is common among indebted firms and also that, ceteris paribus, the likelihood of firms being overlevered is closely linked to low bank efficiency and market capitalization.

The central task of the paper is to test the hypothesis that moderate leverage could boost productivity growth while very high leverage could lead to financial distress and even bankruptcy in response to adverse shocks and could thus lower productivity growth. In this respect, we use a threshold model (a la Hansen, 2000) to endogenously determine the presence and significance of threshold effects of leverage on TFP growth. Threshold estimates identify an upper threshold limit (about 40\% of total assets) beyond which further increases in leverage could adversely affect TFP growth in the sample. Results are robust and hold not only in the full sample, but also in various subsamples including large firms, firms with more intangible assets as well as more profitable firms. Note however that the adverse effects of excessive 
leverage are particularly high for non-profitable firms. There is also suggestion that the leverage thresholds vary across the sample countries at different levels of financial development, thus highlighting the possible role of financial institutions on productivity growth.

Evidence of excess leverage reflects aspects of microeconomic inefficiencies in credit allocation among firms in the sample countries, especially those with weaker financial markets and institutions. While it is essential for firms to deleverage under the circumstances, one also needs to be cautious so that 'virtuous' firms are not starved of essential credit. 


\section{References}

Almeida, H, M. Capello and M. Weisbach. (2005) 'Cash Flow Sensitivity of Cash', The Journal of Finance, vol.59, issue 4, $1777-1804$.

Antoniou, A., Y. Guney and K. Poudiyal. (2008). 'The Determinants of Capital Structure: Capital Market Oriented Versus Bank Oriented Institutions', Journal of Finance and Quantitative Analysis 43(1).

Beck, T, A. Demirgüc-Kunt and V. Maksimovic. (2002). 'Financing Patterns Around the World: The Role of Institutions', World Bank Policy Research Working Paper 2905.

Berger, A.N. and D.B. Humphrey. 1992. 'Measurement and Efficiency Issues in Commercial Banking' in Z. Griliches (ed.) 'Output Measurement in the Service Sectors', NBER studies in Income and Wealth, Vol. 56, University of Chicago Press, Chicago, 245-79.

Berger, A., J.K. Johnson, W. Qinyu and R. De Young. 1997. 'Problem Loans and Cost Efficiency in Commercial Banks', Journal of Banking and Finance 21, 849-870.

Berger, A. and di Patti, E. B. (2006). 'Capital structure and firm performance: a new approach to testing agency theory and an application to the banking industry', Journal of Banking and Finance, 30(4) 1065-1102.

Bernanke, B. and M. Gertler. 1995. 'Inside the Blackbox: Credit Channel of Monetary Policy Transmission' Journal of Economic Perspectives 9, 27-48.

Bonin, J. P. Wachtel and I. Hasan. (2005). 'Privatization Matters: Bank Efficiency in Transition Countries', Journal of Banking and Finance 29(8/9) 2155-2178.

Booth, L. V. Aivazian, A. Demirgüc-Kunt and V. Maksimovic. (2001). 'Capital Structure in Developing Countries', Journal of Finance, 56.

De Haas R. and M. Peters. (2004). 'The Dynamic Adjustment Towards Target Caital Structures of Firms in Transition Economies', EBRD working paper No. 87.

Demirgüc-Kunt, A. and V. Maksimovic. (1995) 'Stock Market Development and Firm Financing Choices', Policy Research Working Paper 1461, The World Bank, Policy Research Department, Finance and Private Sector Development Division, Washington DC.

Driffield, N. and S. Pal. (2010) 'Evolution of Capital Structure in East Asia: Corporate Inertia or Endeavours?, Journal of Royal Statistical Society (Series A), 173(1), 1-29.

Demirguc-Kunt, A. and V Maksimovic. (1998). Law, Finance, and Firm Growth, The Journal of Finance, 1998 - Blackwell Synergy.

EBRD (2009) Transition Report 2009: Transition in Crisis?

Evans, D.S. (1987) 'Tests of Alternative Theories of Firm Growth', The Journal of Political Economy, 1987, vol. 95(4).

Faria, A. and Paolo Mauro (2004) "Institutions and the External Capital Structure of Countries", IMF Working Paper WP/04/236.

Fischer, E.O., Heinkel,R., Zechner,J. (1989) 'Dynamic capital structure choice: theory and tests'. Journal of Finance, 44, $19-40$.

Flannery, M.J. and K. Rangan. (2006) 'Partial Adjustment Toward Target Capital Structures', Journal of Financial Economics 79, 469-506.

Frank, M. and B. Goyal. (2009). 'Capital Structure Decisions: Which Factors are Reliably Important?" (with Murray Z. Frank), Financial Management, 38(1), 1-37.

Girma, S. (2005). 'Absorptive Capacity and Productivity Spillovers from FDI: A Threshold Regression Analysis', Oxford Bulletin of Economics and Statistics 67(3) 281-306.

Girma,S., M. Henry, R. Kneller and C. Milner (2003)Threshold and Interaction Effects in the 
Openness-Productivity Growth Relationship: The Role of Institutions and Natural Barriers GEP working paper 2003/32, Nottingham.

Goldstein, R., N. Ju and H. Leland. (2001) An EBIT based Model of Dynamic Capital Structure', Journal of Business 74(4).

Greenspan, A. (2002). Testimony of Chairman Alan Greenspan Federal Reserve Board's Semi Annual Monetary Policy Report to the Congress Before the Committee on Financial Services, US House of Representatives February 27.

Griffith, R. (1999). Using the ARD establishment level data to look at foreign ownership and productivity in the United Kingdom. Economic Journal, 109, 416-42.

Hansen, B. E. (2000). 'Sample splitting and threshold estimation', Econometrica, Vol. 68, 575-603.

Hovakimian, A., G. Hovakimian., and H. Tehranian (2004) 'Determinants of target capital structure: The case of dual debt and equity issues'. Journal of Financial Economics, Volume 71 (3), 517-540.

Kyotaki, N. and J. Moore. (1997). 'Credit Cycles', Journal of Political Economy, 105, 211-248.

Lang, L., E. Ofek and R. M. Stulz (1996) "Leverage, investment, and firm growth", Journal of Financial Economics, 40, 3-29.

Levinsohn, J. and Petrin, A. (2003). Estimating production functions using Inputs to control for unobservables. Review of Economic Studies, 70, 317-341.

Myers, S.C. (1984) 'Capital Structure Puzzles', Journal of Finance, 39, 575-92.

Myers, S.C. and N. Majluf. (1984). 'Corporate Financing and Investment Decisions when Firms Have Information Investors do not Have, Journal of Financial Economics, 13, 187-221.

Nivrozhkin, E. (2005). 'The Dynamics of Capital Structure in Transition Economies', Economics of Planning.

Olley, S. and Pakes, A. (1996). The Dynamics of Productivity in the Telecommunications Equipment Industry. Econometrica, 64 (6), 1263-98.

Rajan, R. and L. Zingales. (1995) 'What Do We Know About Capital Structure? Some evidence from international data,' Journal of Finance, 50, 1421-1460.

Rogoff, K. (1999). "International Institutions for Reducing Global Financial Instability," Journal of Economic Perspectives, American Economic Association, 13(4), 2.

Sarkar, S. and F. Zapatero. (2003). 'The Trade-off Model with Mean Reverting Earnings: Theory and Empirical Tests', Economic Journal.

Strebulaev, I. (2007). 'Do Tests of Capital Structure Theory Mean What They Say?', Journal of Finance 62, 1747-1788. 
Table 1: Cross-country variation in leverages 2001-2005

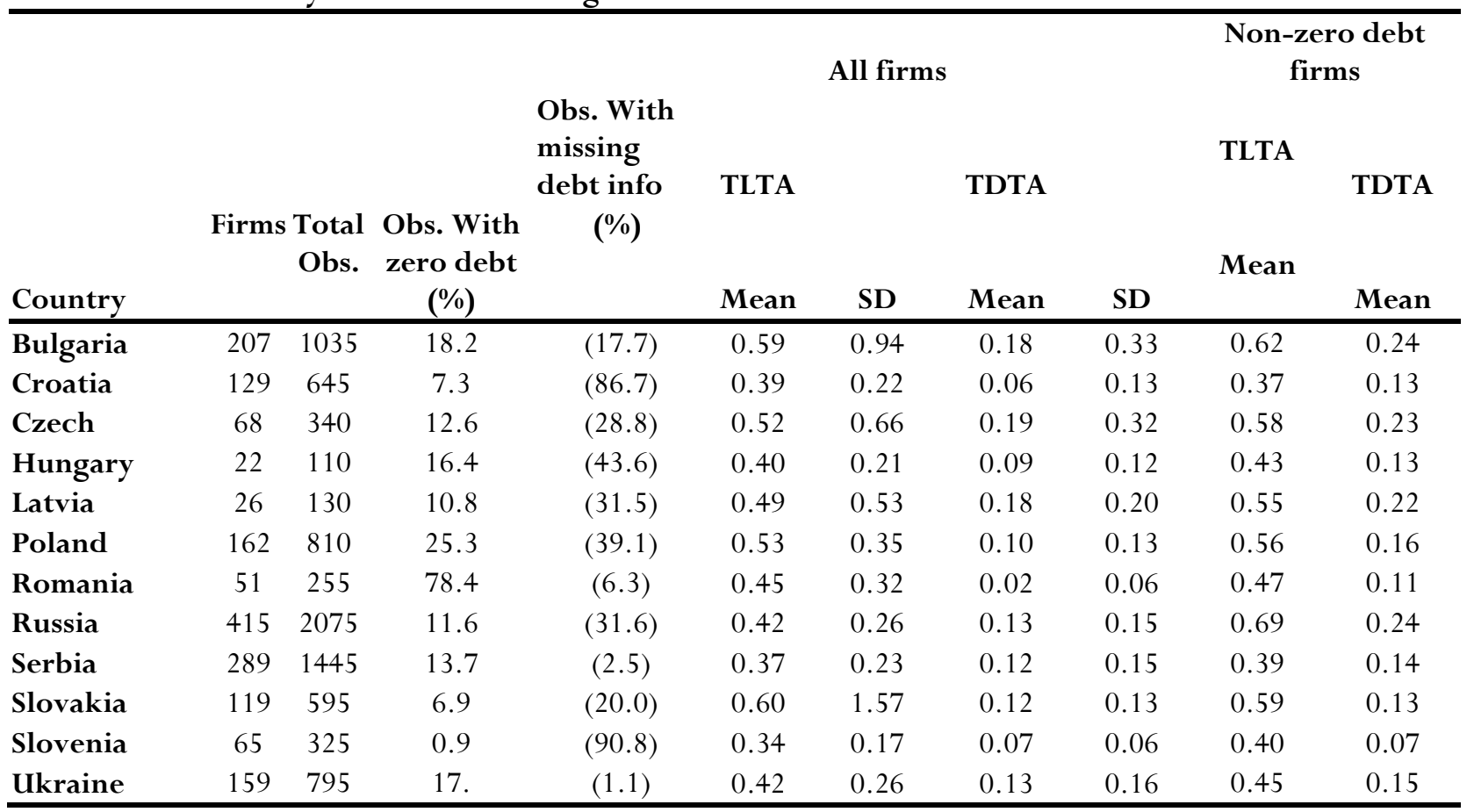

Note: TL/TA is the total liability as a share of total assets while TD/TA is total debt (both short and long-run) to total assets.

Source: Authors' own calculation using Orbis data. 
Table 2: Distribution of debt ratio among firms with positive debt, 2001-2005

\begin{tabular}{|c|c|c|c|c|c|c|c|c|c|}
\hline \multirow[b]{2}{*}{ Country } & \multicolumn{6}{|c|}{ Leverage percentiles } & \multicolumn{3}{|c|}{ Average leverage by size (by total assets) } \\
\hline & $25 \%$ & $50 \%$ & $75 \%$ & $90 \%$ & $95 \%$ & $99 \%$ & $\begin{array}{c}\text { Small \& medium } \\
\text { firms }\end{array}$ & Large & $\begin{array}{c}\text { Correlation } \\
\text { (size, leverage) }\end{array}$ \\
\hline Bulgaria & 0.05 & 0.13 & 0.28 & 0.53 & 0.70 & 1.55 & 0.22 & 0.25 & -0.0213 \\
\hline Croatia & 0.013 & 0.11 & 0.19 & 0.24 & 0.42 & 0.83 & 0.06 & 0.18 & $0.304 *$ \\
\hline Czech Republic & 0.045 & 0.14 & 0.27 & 0.40 & 0.97 & 2.19 & 0.20 & 0.25 & 0.013 \\
\hline Hungary & 0.009 & 0.14 & 0.18 & 0.24 & 0.29 & 0.65 & 0.13 & 0.13 & -0.054 \\
\hline Latvia & 0.07 & 0.16 & 0.27 & 0.52 & 0.71 & 0.82 & 0.27 & 0.19 & -0.163 \\
\hline Poland & 0.06 & 0.13 & 0.23 & 0.36 & 0.44 & 0.68 & 0.18 & 0.15 & $-0.147 *$ \\
\hline Romania & 0.015 & 0.07 & 0.16 & 0.21 & 0.27 & 0.70 & 0.09 & 0.12 & 0.163 \\
\hline Russia & 0.06 & 0.15 & 0.33 & 0.51 & 0.61 & 1.3 & 0.27 & 0.19 & $-0.19 *$ \\
\hline Serbia & 0.03 & 0.08 & 0.21 & 0.35 & 0.44 & 0.65 & 0.12 & 0.16 & $0.217 *$ \\
\hline Slovakia & 0.033 & 0.096 & 0.18 & 0.30 & 0.38 & 0.64 & 0.11 & 0.15 & $0.153 *$ \\
\hline Slovenia & 0.032 & 0.07 & 0.12 & 0.15 & 0.17 & 0.20 & - & 0.07 & 0.270 \\
\hline Ukraine & 0.036 & 0.10 & 0.22 & 0.38 & 0.47 & 0.72 & 0.17 & 0.15 & $-0.093 *$ \\
\hline
\end{tabular}

Source: Authors' own calculation using Orbis data. 
Table 3: Distribution of Excess leverage in the sample countries

\begin{tabular}{lllll}
\hline & \multicolumn{3}{c}{ All firms with debt>0 } \\
\hline & \multicolumn{2}{l}{$\begin{array}{l}\text { Proportion of firms with } \\
\text { Excess leverage } \mathbf{L}-\mathbf{L}^{*} \mathbf{*} \mathbf{0}\end{array}$} & \multicolumn{2}{l}{$\begin{array}{l}\text { Average gap for firms with excess } \\
\text { leverage }\end{array}$} \\
Country & Debt ratio & Liability ratio & Debt ratio & Liability ratio \\
\hline Bulgaria & 0.7575 & 0.7515 & 1.78 & 1.9079 \\
Croatia & 0.8372 & 0.6977 & 2.32 & 1.1916 \\
Czech Republic & 0.7789 & 0.8040 & 2.0477 & 1.2136 \\
Hungary & 0.7955 & 0.7727 & 1.42 & 1.1009 \\
Latvia & 0.8133 & 0.7867 & 1.7852 & 1.1360 \\
Poland & 0.8541 & 0.7951 & 2.5587 & 1.1912 \\
Romania & 0.5451 & 0.7490 & 3.787 & 1.2433 \\
Russia & 0.8226 & 0.7776 & 2.1171 & 3.0655 \\
Serbia & 0.7944 & 0.8026 & 2.89 & 1.2986 \\
Slovakia & 0.7563 & 0.7632 & 1.94 & 1.7744 \\
Slovenia & 0.6667 & 0.8519 & 1.2779 & 1.1706 \\
Ukraine & 0.7392 & 0.7824 & 1.7866 & 1.2191 \\
\hline
\end{tabular}

Source: Authors' own calculation using Orbis data. 
Table 4. Financial institutional in CEE countries 2001-2005

\begin{tabular}{|c|c|c|c|c|c|c|c|c|c|}
\hline COUNTRY & $\begin{array}{c}\text { [1] Size of } \\
\text { the banking } \\
\text { sector }\end{array}$ & $\begin{array}{l}\text { [1] Efficiency } \\
\text { of the } \\
\text { banking } \\
\text { sector }\end{array}$ & $\begin{array}{c}{[1]} \\
\text { Stability of } \\
\text { the } \\
\text { banking } \\
\text { sector }\end{array}$ & $\begin{array}{l}\text { [1] Equity } \\
\text { market } \\
\text { efficiency }\end{array}$ & $\begin{array}{c}\text { [3] Market } \\
\text { capitalization } \\
\text { to GDP }\end{array}$ & $\begin{array}{c}{[2]} \\
\text { Creditors' } \\
\text { rights }\end{array}$ & $\begin{array}{c}\text { [3] Share of } \\
\text { foreign } \\
\text { banks }\end{array}$ & $\begin{array}{c}\text { [3] Bank } \\
\text { reform }\end{array}$ & $\begin{array}{l}\text { [3] } \\
\text { Competition } \\
\text { reform }\end{array}$ \\
\hline Bulgaria & 4.84 & 5.51 & 4.64 & 6.68 & 8.74 & 2.00 & 77.34 & 3.40 & 2.38 \\
\hline Croatia & 5.76 & 4.89 & 4.42 & NA & 23.69 & 3.00 & 89.64 & 3.74 & 2.30 \\
\hline Czech Republic & 5.35 & 4.72 & 5.01 & 3.55 & 22.69 & 3.00 & 86.10 & 3.76 & 2.94 \\
\hline Hungary & 5.21 & 5.37 & 4.70 & 4.23 & 23.51 & 1.00 & 76.12 & 4.00 & 3.12 \\
\hline Latvia & 4.71 & 5.34 & 3.47 & 4.78 & 10.38 & 3.00 & 53.50 & 3.62 & 2.60 \\
\hline Poland & 5.07 & 5.67 & 5.04 & 5.03 & 20.77 & 1.00 & 72.00 & 3.38 & 3.06 \\
\hline Romania & 3.95 & 4.23 & 4.69 & 3.85 & 11.03 & 1.67 & 55.36 & 2.82 & 2.30 \\
\hline Russian Federation & 4.5 & 5.04 & 4.82 & 3.00 & 46.59 & 1.67 & 8.04 & 2.00 & 2.30 \\
\hline Serbia & NA & 4.51 & NA & NA & 10.17 & 2.00 & 36.46 & 2.12 & 1.00 \\
\hline Slovakia & 5.52 & 4.76 & 6.07 & NA & 7.84 & 2.00 & 90.54 & 3.46 & 3.12 \\
\hline Slovenia & 5.43 & 5.09 & 3.77 & 4.55 & 23.38 & 3.00 & 18.74 & 3.30 & 2.70 \\
\hline Ukraine & 4.49 & 4.68 & 2.05 & NA & 12.12 & 2.00 & 2.30 & 13.98 & 3.32 \\
\hline
\end{tabular}

[1]: Source: FSDI, World Bank. [2] Source: La Porta et al. [3] Source EBRD. 
Table 5. Mean comparison of selected characteristics of firms with/without excess debt ratio 2001-2005

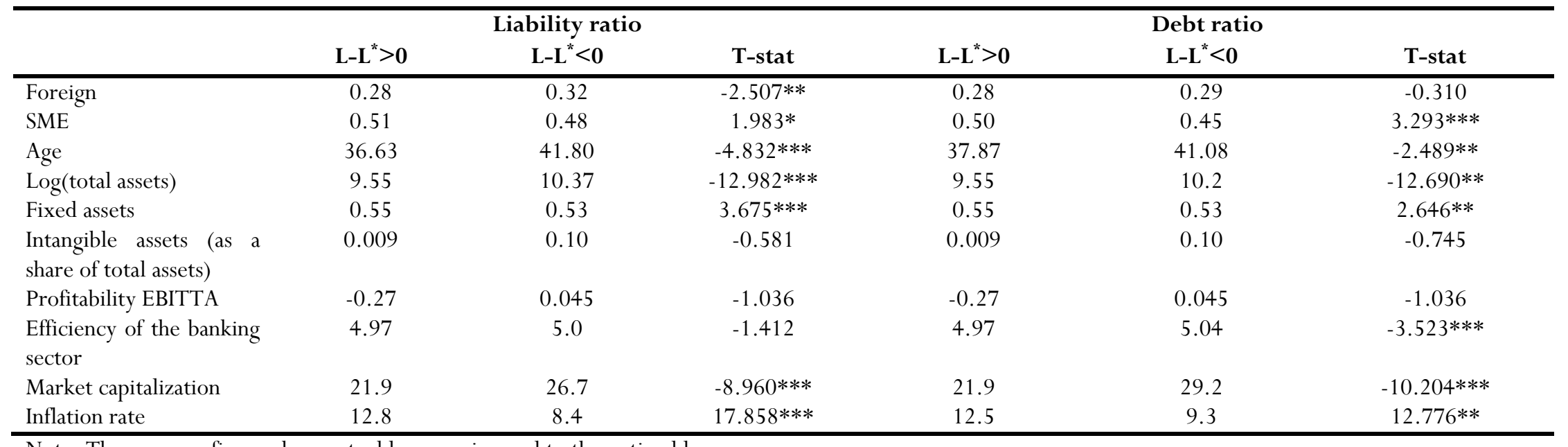

Note: There are no firms where actual leverage is equal to the optimal leverage.

Foreign=1 if firm is foreign-owned; 0 otherwise.SME= 1 if a firm is in quartiles 1 and 2 of the sample distribution of total assets and 0 otherwise. Age: number of years since the firm was incorporated; Total assets are measured in USD thousands; fixed assets are measured in USD thousands. Intangible assets are the ratio of intangible fixed assets to total assets. Profitability is measured as the ratio of earnings before interests and taxes (EBIT) to total assets. Bank efficiency refers to the FSDI Index (1-5) of banking sector efficiency where a higher value means greater efficiency. Market capitalization rate is the ratio of market capitalisation to GDP (in \%). Inflation refers to the CPI inflation (in \%)

Source: Authors' own calculation using Orbis data. 
Table 6. Determinants of Excess Leverage: Conditional Fixed Effects Logit Estimates

\begin{tabular}{lcccc}
\hline & \multicolumn{2}{c}{ All firms } & $(2)$ & \multicolumn{2}{c}{ Non-zero debt firms } \\
VARIABLES & EXCESSTD & EXCESSTL & EXCESSTD & EXCESSTL \\
\hline Small \& medium & -0.0330 & -0.0385 & -0.0571 & -0.0648 \\
firms & & & & \\
& $(0.0303)$ & $(0.0334)$ & $(0.0415)$ & $(0.0439)$ \\
Age & $-0.151 * * *$ & $-0.141 * * *$ & $-0.142 * * *$ & $-0.127 * *$ \\
& $(0.00690)$ & $(0.00760)$ & $(0.00905)$ & $(0.00957)$ \\
Intangible assets & 0.460 & -0.103 & 0.556 & -0.0151 \\
& $(0.310)$ & $(0.342)$ & $(0.366)$ & $(0.387)$ \\
Fixed assets & $0.130 * *$ & 0.000633 & $0.185 * *$ & 0.00592 \\
& $(0.0662)$ & $(0.0729)$ & $(0.0873)$ & $(0.0923)$ \\
Profitability & $-0.0682 *$ & $-0.176 * * *$ & $-0.124 * *$ & $-0.164 * * *$ \\
& $(0.0393)$ & $(0.0433)$ & $(0.0510)$ & $(0.0540)$ \\
Bank efficiency & $-0.139 * * *$ & $-0.103 * * *$ & $-0.111 * * *$ & $-0.108 * * *$ \\
& $(0.0149)$ & $(0.0164)$ & $(0.0203)$ & $(0.0214)$ \\
Market capitalisation & $-0.00261 * *$ & $-0.00253 * *$ & 0.00165 & $-0.00265 *$ \\
& $(0.00108)$ & $(0.00119)$ & $(0.00131)$ & $(0.00138)$ \\
Inflation & $0.00932 * * *$ & $0.00457 * *$ & 0.00288 & 0.00310 \\
& $(0.00173)$ & $(0.00190)$ & $(0.00249)$ & $(0.00263)$ \\
Constant & $6.648 * *$ & $6.324 * * *$ & $5.868 * * *$ & $5.550 * * *$ \\
& $(0.254)$ & $(0.280)$ & $(0.294)$ & $(0.311)$ \\
Observations & 4534 & 4534 & 3084 & 3084 \\
Number of firms & 1133 & 1133 & 915 & 915 \\
R-squared & 0.327 & 0.301 & 0.279 & 0.276 \\
\hline
\end{tabular}

Standard errors in parentheses; $* * * p<0.01, * * p<0.05, * p<0.1$

Note: The dependent variable (Excesstd, Excesstl) is equal to 1 if the firm has excess leverage (debt and liability ratio respectively) and 0 otherwise. See note to Table 5 for variable definitions. 
Table 7. Threshold estimation of determinants of TFP growth (all firms)

\begin{tabular}{|c|c|c|c|c|c|}
\hline Variable & (1) Coefficient & t-statistic & Variable & (2) Coefficient & t-statistic \\
\hline Initial TFP & 0.126699 & 0.959595 & Initial TFP & 0.127223 & 0.960581 \\
\hline TDTA $>0.404$ & -0.024226 & $-3.21458 * *$ & TLTA $>0.412$ & -0.204268 & $-2.40342 * *$ \\
\hline $0.322<$ TDTA $<0.404$ & 0.089215 & $2.930289 * *$ & $0.348<$ TLTA $<0.412$ & 0.058413 & $1.915012 *$ \\
\hline TDTA $<0.322$ & 0.350741 & $1.82689 *$ & TLTA $<0.348$ & 0.394431 & $2.36437 * *$ \\
\hline Small/Medium firms & 0.143156 & $2.77914 * *$ & Small/Medium firms & 0.147616 & $2.88400 * *$ \\
\hline Young firms & $-3.34 \mathrm{E}-03$ & -0.077172 & Young firms & $-6.97 \mathrm{E}-03$ & -0.161321 \\
\hline Foreign firms & 0.280277 & 1.38231 & Foreign firms & 0.295057 & $1.45004 *$ \\
\hline Intangible assets & -2.26983 & $-3.71606 * *$ & Intangible assets & -2.1469 & $-3.52047 * *$ \\
\hline Bank efficiency & 0.095357 & $2.57299 * *$ & Bank efficiency & 0.092482 & $2.49775 * *$ \\
\hline Market capitalisation & 0.010349 & $4.02834 * *$ & Market capitalisation & 0.010322 & $4.01593 * *$ \\
\hline Intercept & 0.449349 & $1.60934 *$ & Intercept & 0.365951 & 1.29955 \\
\hline Sector & Yes & & Sector & Yes & \\
\hline R-square & 0.042 & & R-square & 0.039 & \\
\hline $95 \%$ CI for $\gamma$ & $0.322-0.404$ & & $95 \%$ CI for $\gamma$ & $0.348-0.412$ & \\
\hline
\end{tabular}

Note: * denotes significance at $10 \%$ or lower level while '**' denotes the same at $1 \%$ or lower level. See note to Table 5 for variable definitions. A firm is defined as young if it is incorporated in or after 1995. These estimates are based on data from 9 of the sample countries and exclude firms from Croatia, Romania and Serbia. This is because we could not find industry-level deflators for these countries and hence we could not calculate the TFP residuals. 
Table 8. Threshold estimation of determinants of TFP growth (non-zero debt firms)

\begin{tabular}{lcclcc}
\hline Variable & (1) Coefficient & t-statistic & Variable & $(2)$ Coefficient & t-statistic \\
\hline Initial TFP & 0.155852 & 1.06343 & Initial TFP & 0.168956 & 1.14858 \\
TDTA $>\mathbf{0 . 3 9 9}$ & -0.438213 & $-4.22543 * *$ & TLTA $>\mathbf{0 . 4 0 6}$ & -0.279262 & $-5.21194 * *$ \\
$\mathbf{0 . 3 1 8}<$ TDTA $<\mathbf{0 . 3 9 9}$ & 0.088776 & $2.468972 * *$ & $\mathbf{0 . 3 5 4}<$ TLTA $<\mathbf{0 . 4 0 6}$ & 0.084452 & $2.62755 * *$ \\
TDTA $<\mathbf{0 . 3 1 8}$ & 0.23567 & $3.118497 * *$ & TLTA<0.406 & 0.585551 & $4.25187 * *$ \\
Small/Medium firms & 0.203393 & $3.64635 * *$ & Small/Medium firms & 0.202249 & $3.67908 * *$ \\
Young firms & -0.02566 & -0.577607 & Young firms & -0.017047 & -0.387835 \\
Foreign firms & 0.421101 & $1.96136 * *$ & Foreign firms & 0.437864 & $2.03162 * *$ \\
Intangible assets & -1.79247 & $-2.86757 * *$ & Intangible assets & -1.6335 & $-2.64248 * *$ \\
Bank efficiency & 0.074301 & $1.87058 *$ & Bank efficiency & 0.070297 & $1.79326 *$ \\
Market capitalisation & $9.31 \mathrm{E}-03$ & $3.35352 * *$ & Market capitalisation & $9.87 \mathrm{E}-03$ & $3.59513 * *$ \\
Intercept & 0.409825 & 1.35935 & Intercept & 0.231641 & 0.766973 \\
Sector & Yes & Sector & Yes & $\mathbf{0 . 0 4}$ \\
R-square & 0.054 & R-square & $0.354-0.406$ \\
95\% CI for $\boldsymbol{\gamma} \mathbf{2}$ & $0.318-0.399$ & $\mathbf{9 5 \%}$ CI for $\boldsymbol{\gamma} \mathbf{2}$ &
\end{tabular}

Note: Note: $*$ denotes significance at $10 \%$ or lower level while ' $* *$ ' denotes the same at $1 \%$ or lower level. See notes to Table 5 and 7 for variable definitions. These estimates are based on data from 9 of the sample countries and exclude firms from Croatia, Romania and Serbia. This is because we could not find industrylevel deflators for these countries and hence we could not calculate the TFP residuals. 
Table 9. Threshold estimation of determinants of TFP growth for profitable and non-profitable firms with positive debt:

\begin{tabular}{|c|c|c|c|c|c|c|c|c|}
\hline & $\begin{array}{r}\text { Firms with } \\
\text { profit }<0.04\end{array}$ & & $\begin{array}{c}\text { Firms with } \\
\text { profit }>0.04\end{array}$ & & $\begin{array}{c}\text { firms with } \\
\text { ROCE }<0.04\end{array}$ & & $\begin{array}{c}\text { Firms with } \\
\text { ROCE } \\
>0.04\end{array}$ & \\
\hline Variable & Coefficient & t-statistic & Coefficient & t-statistic & Coefficient & t-statistic & Coefficient & t-statistic \\
\hline Initial TFP & 0.0271 & 0.1513 & 0.2294 & 1.3229 & 0.0135 & 0.0755 & 0.2279 & 1.3169 \\
\hline TDTA+ & -0.5982 & $-3.0784 * *$ & -0.0227 & $-3.2838 * *$ & -0.7655 & $-4.187 * *$ & -0.1421 & $-3.1335 * *$ \\
\hline TDTA $=$ & 0.5340 & $2.2141 * *$ & -0.0531 & -1.5035 & -0.0043 & -0.0094 & 0.1067 & $2.5672 * *$ \\
\hline TDTA- & 0.2419 & $3.5171 * *$ & 0.1596 & 2.1746 & 0.5536 & $2.0419 * *$ & 0.2776 & $1.45586 *$ \\
\hline Small/medium firms & 0.11553 & 0.9091 & 0.1561 & $2.7733 * *$ & 0.1223 & $2.9300 * *$ & 0.1593 & $2.8338 * *$ \\
\hline YOUNG firms & -0.2041 & $-1.7376 *$ & 0.0077 & 0.1814 & -0.2084 & $-1.7157 *$ & 0.0076 & 0.1800 \\
\hline FOREIGN firms & 0.1367 & 0.5405 & 0.6022 & $2.4505 * *$ & 0.1272 & 0.5062 & 0.5997 & $2.4458 * *$ \\
\hline Intangible assets & -0.2763 & -0.1099 & -1.5836 & $-3.00466 * *$ & 0.0953 & 0.0373 & -1.7853 & $-3.3797 * *$ \\
\hline Bank efficiency & 0.2745 & $2.2474 * *$ & 0.039713 & 1.1451 & 0.2648 & $2.0524 * *$ & 0.0381 & 1.0977 \\
\hline $\begin{array}{c}\text { Market } \\
\text { capitalisation }\end{array}$ & 0.0097 & 1.0607 & 0.0088 & $3.56645 * *$ & 0.00688 & 0.711086 & 0.0084 & $3.4425 * *$ \\
\hline Sector & Yes & & Yes & & Yes & & Yes & \\
\hline Intercept & -0.4250 & -0.7062 & 0.5280 & $1.5874 *$ & -0.2747 & -0.4455 & 0.5668 & $1.7083 *$ \\
\hline R-square & 0.078 & & 0.063 & & 0.048 & & 0.068 & \\
\hline threshold & 0.224 & & 0.577 & & 0.425 & & 0.522 & \\
\hline threshold range & $\begin{array}{c}0.187- \\
0.301\end{array}$ & & $0.509-0.624$ & & $0.354-0.496$ & & $0.453-0.616$ & \\
\hline
\end{tabular}

Note: These estimates use effects of debt ratio on TFP growth. * denotes significance at $10 \%$ or lower level while ‘ $* *$ ' denotes the same at $1 \%$ or lower level. See note to Tables 5 and 7 for variable definitions. These estimates are based on data from 9 of the sample countries and exclude firms from Croatia, Romania and Serbia. This is because we could not find industry-level deflators for these countries and hence we could not calculate the TFP residuals. TDTA+, TLTA+ refer to values of leverage in excess of the upper threshold; TDTA $=, T L T A=$ refer to the values of leverage between the upper and lower threshold while TDTA-, TLTA- refer to the values of leverage below the lower threshold. 
Table 10. Percentage distribution of indebted firms with excess leverage

\begin{tabular}{|c|c|c|c|}
\hline & All non-zero debt firms & $\begin{array}{l}\text { Profitable non-zero debt firms } \\
\text { (by profit margin) }\end{array}$ & $\begin{array}{l}\text { Non-profitable non-zero debt firms } \\
\text { (by profit margin) }\end{array}$ \\
\hline Country & Debt ratio $\gamma_{2}>0.399$ & Debt ratio $\gamma_{2}>0.577$ & debt ratio $\gamma_{2}>0.301$ \\
\hline Bulgaria & 0.1657 & 0.0226 & 0.0798 \\
\hline Czech Republic & 0.1055 & 0.0101 & 0.0503 \\
\hline Hungary & 0.0455 & 0.0000 & 0.0227 \\
\hline Latvia & 0.1733 & 0.0133 & 0.0533 \\
\hline Poland & 0.0625 & 0.0069 & 0.0104 \\
\hline Russian Federation & 0.1959 & 0.0348 & 0.0365 \\
\hline Slovakia & 0.0322 & 0.0092 & 0.0115 \\
\hline Slovenia & 0.00 & 0.0000 & 0.000 \\
\hline Ukraine & 0.0864 & 0.0108 & 0.0278 \\
\hline
\end{tabular}

Note: These estimates make use of the threshold parameters obtained in Tables 8 (all non-zero debt firms) and 9 (profitable and non-profitable firms). 
Table 11. Inter-country variation in threshold estimates for debt and liability ratios: Selected estimates (95\% confidence intervals between brackets)

$$
\text { (1) (2) }
$$

(3)

\begin{tabular}{|c|c|c|c|c|c|c|}
\hline & \multirow[b]{2}{*}{$\begin{array}{l}\text { Bank } \\
\text { efficiency }\end{array}$} & \multirow[b]{2}{*}{$\begin{array}{l}\text { Market } \\
\text { capitalization }\end{array}$} & \multicolumn{2}{|c|}{ Debt ratio } & \multicolumn{2}{|c|}{ Liability ratio } \\
\hline & & & All firms & $\begin{array}{l}\text { Non-zero debt } \\
\text { firms }\end{array}$ & All firms & $\begin{array}{l}\text { Non-zero debt } \\
\text { firms }\end{array}$ \\
\hline Bulgaria & 5.51 & 8.74 & $0.354(0.307,0.387)$ & $\begin{array}{l}0.307(0.288 \\
0.367)\end{array}$ & $0.354(0.310,0.366)$ & $\begin{array}{l}0.339(0.269 \\
0.384)\end{array}$ \\
\hline Poland & 5.07 & 20.77 & $0.409(0.366,0.437)$ & $\begin{array}{l}0.388(0.344, \\
0.441)\end{array}$ & $0.399(0.328,0.451)$ & $\begin{array}{l}0.415(0.377 \\
0.463)\end{array}$ \\
\hline \multicolumn{7}{|l|}{ Romania } \\
\hline Russia & 5.04 & 46.6 & $0.514(0.439,0.570)$ & $\begin{array}{l}0.529(0.446 \\
0.604)\end{array}$ & $0.514(0.491,0.561)$ & $\begin{array}{l}0.547(0.449 \\
0.674)\end{array}$ \\
\hline Serbia & 4.51 & 10.2 & $0.288(0.266,0.344)$ & $\begin{array}{l}0.327(0.276 \\
0.388)\end{array}$ & $0.347(0.310,0.397)$ & $\begin{array}{l}0.377(0.354 \\
0.406)\end{array}$ \\
\hline Ukraine & 4.68 & 12.12 & $0.461(0.377,0.503)$ & $\begin{array}{l}0.442(0.394 \\
0.505)\end{array}$ & $0.439(0.399,0.488)$ & $\begin{array}{l}0.483(0.450 \\
0.509)\end{array}$ \\
\hline
\end{tabular}

Note: Columns (1) and (2) show the average values of indices of bank efficiency and market capitalization. Column (3) shows the estimate of leverage threshold and also the lower and upper limits of the leverage threshold (in the parentheses) for debt and liability ratio for all firms as well as indebted firms only. 
Figure 1. Growth of domestic credit to GDP in the CEE region

Growth of domestic credit to GDP (\%)

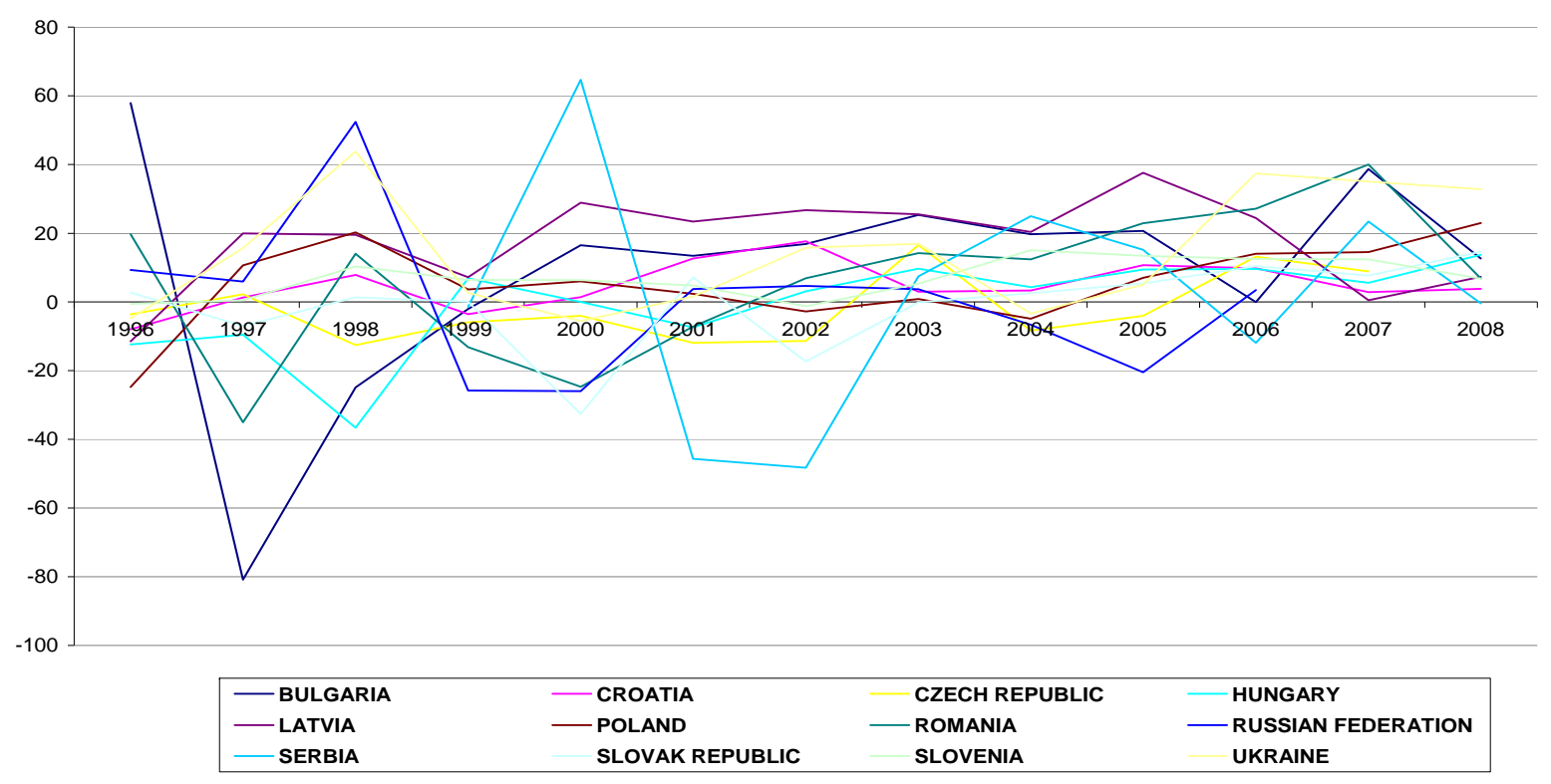


Figure 2. Distribution of TFP growth in sample countries

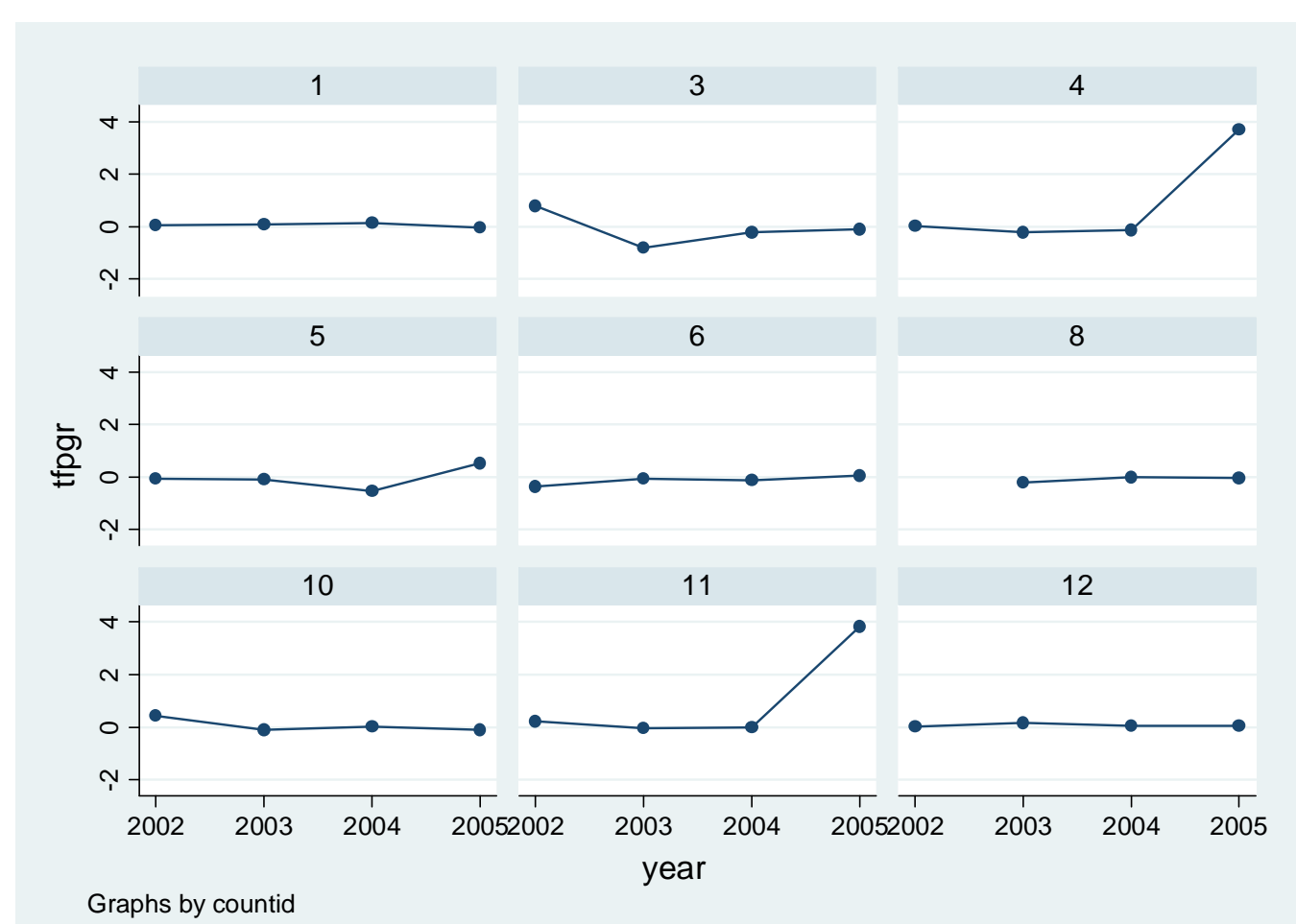

Note: List of countries: 1: Bulgaria; 3: Czech Republic; 4: Hungary; 5: Latvia; 6: Poland; 8: Russia; 10: Slovakia; 11: Slovenia; 12: Ukraine. 
Appendix 1

Table A1. First-stage fixed effects estimates of debt ratio 2001-2005

\begin{tabular}{lcccccc}
\hline & Bulgaria & Croatia & Czech & Hungary & Latvia & Poland \\
& $(1)$ & $(2)$ & $(3)$ & $(4)$ & $(5)$ & $(6)$ \\
\hline Log assets & $0.134^{* * *}$ & 0.412 & -0.0459 & $-0.474^{* *}$ & -0.226 & $0.0428^{* *}$ \\
& $(0.0434)$ & $(0.440)$ & $(0.0609)$ & $(0.159)$ & $(0.228)$ & $(0.0216)$ \\
Asset growth & -0.0204 & $-0.435^{*}$ & 0.00247 & 0.192 & -0.0433 & $-0.00424^{*}$ \\
& $(0.0223)$ & $(0.200)$ & $(0.00236)$ & $(0.129)$ & $(0.109)$ & $(0.00243)$ \\
age & -0.0181 & -0.0689 & -0.0369 & $0.119^{*}$ & 0.0451 & 0.00190 \\
& $(0.0142)$ & $(0.0994)$ & $(0.0291)$ & $(0.0445)$ & $(0.0346)$ & $(0.0143)$ \\
fixed assets & $-0.224 * *$ & 0.310 & -0.122 & 0.362 & -0.103 & $0.202^{*}$ \\
& $(0.109)$ & $(0.790)$ & $(0.214)$ & $(0.503)$ & $(0.270)$ & $(0.117)$ \\
intangible assets & 0.135 & -1.462 & $-2.624 * *$ & $-12.29 * *$ & $-0.647 * *$ & 0.0377 \\
& $(0.699)$ & $(2.311)$ & $(1.132)$ & $(3.264)$ & $(0.317)$ & $(0.349)$ \\
profitability & $-0.844^{* * *}$ & 0.0877 & -0.0679 & 0.573 & 0.632 & 0.111 \\
& $(0.0712)$ & $(0.699)$ & $(0.117)$ & $(0.408)$ & $(1.563)$ & $(0.0870)$ \\
Shareholder's funds & $0.299 * * *$ & -0.0263 & $0.733 * * *$ & 0.628 & -0.712 & -0.0747 \\
& $(0.0927)$ & $(0.478)$ & $(0.185)$ & $(0.674)$ & $(0.782)$ & $(0.0698)$ \\
Industry_median & 0.0682 & 0.663 & 0.269 & 0.0112 & 0.374 & 0.140 \\
& $(0.0675)$ & $(0.561)$ & $(0.213)$ & $(0.771)$ & $(0.415)$ & $(0.122)$ \\
inflation & -0.00353 & 0.0295 & 0.0328 & -0.00310 & -0.00716 & 0.000275 \\
& $(0.00533)$ & $(0.0838)$ & $(0.0202)$ & $(0.00841)$ & $(0.0162)$ & $(0.00666)$ \\
Constant & -0.101 & -0.107 & 1.148 & 1.277 & 1.391 & -0.230 \\
& $(0.526)$ & $(2.818)$ & $(0.761)$ & $(1.212)$ & $(2.268)$ & $(0.433)$ \\
Observations & 332 & 37 & 89 & 22 & 30 & 204 \\
Number of firms & 131 & 16 & 33 & 9 & 13 & 91 \\
R-squared & 0.483 & 0.495 & 0.309 & 0.987 & 0.417 & 0.096 \\
\hline
\end{tabular}

Standard errors in parentheses; $* * * p<0.01,{ }^{* *} \mathrm{p}<0.05,{ }^{*} \mathrm{p}<0.1$; all variables are lagged by one year. See note to Table 5 for variable definitions. 
Table A1 (continued). First-stage fixed effects estimates of debt ratio 2001-2005

\begin{tabular}{|c|c|c|c|c|c|c|}
\hline & $\begin{array}{c}\text { Romania } \\
\text { (7) }\end{array}$ & $\begin{array}{c}\text { Russia } \\
\text { (8) }\end{array}$ & $\begin{array}{c}\text { Serbia } \\
\text { (9) }\end{array}$ & $\begin{array}{c}\text { Slovakia } \\
(10)\end{array}$ & $\begin{array}{c}\text { Slovenia } \\
(11)\end{array}$ & $\begin{array}{c}\text { Ukraine } \\
\text { (12) }\end{array}$ \\
\hline \multirow[t]{2}{*}{ Log assets } & $7.92 \mathrm{e}-05$ & $7.92 \mathrm{e}-05$ & 0.000788 & -0.00648 & $1.607^{*}$ & $0.0472 * *$ \\
\hline & $(5.59 e-05)$ & (5.59e-05) & $(0.0314)$ & $(0.0422)$ & $(0.898)$ & $(0.0234)$ \\
\hline \multirow{2}{*}{ Asset growth } & $-2.39 e-05$ & $-2.39 e-05$ & 0.0293 & 0.0231 & 0.396 & -0.0137 \\
\hline & $(3.24 \mathrm{e}-05)$ & $(3.24 \mathrm{e}-05)$ & $(0.0216)$ & $(0.0214)$ & $(0.165)$ & $(0.0126)$ \\
\hline \multirow[t]{2}{*}{ age } & $-5.34 \mathrm{e}-05$ & $-5.34 \mathrm{e}-05$ & $0.0180 *$ & $0.0386^{*}$ & -0.151 & -0.00603 \\
\hline & $(0.000113)$ & $(0.000113)$ & $(0.0103)$ & $(0.0194)$ & $(0.144)$ & $(0.114)$ \\
\hline \multirow[t]{2}{*}{ fixed assets } & $-2.95 e-05$ & $-2.95 e-05$ & 0.0166 & $0.174^{*}$ & -2.227 & -0.0346 \\
\hline & $(0.000135)$ & $(0.000135)$ & $(0.0618)$ & $(0.0877)$ & (1.913) & $(0.0827)$ \\
\hline \multirow[t]{2}{*}{ intangible assets } & $-0.00212 * *$ & $-0.00212 *$ & 0.0965 & -0.356 & 0.334 & 0.253 \\
\hline & $(0.00103)$ & $(0.00113)$ & $(0.162)$ & $(0.284)$ & (4.698) & (1.037) \\
\hline \multirow[t]{2}{*}{ profitability } & -0.000125 & -0.000125 & 0.0313 & -0.105 & $1.530 *$ & $0.0432 *$ \\
\hline & $(0.000146)$ & $(0.000146)$ & $(0.0755)$ & $(0.0813)$ & $(0.788)$ & $(0.0223)$ \\
\hline \multirow[t]{2}{*}{ Shareholder's funds } & $6.78 \mathrm{e}-05$ & $6.78 \mathrm{e}-05$ & -0.0512 & 0.00411 & $4.498 * *$ & -0.00800 \\
\hline & $(8.74 \mathrm{e}-05)$ & $(8.74 \mathrm{e}-05)$ & $(0.0556)$ & $(0.00714)$ & (2.165) & $(0.0645)$ \\
\hline \multirow[t]{2}{*}{ Industry_median } & $-0.00139 * * *$ & $-0.00139 * * *$ & 0.129 & -0.135 & $-1.959 *$ & -0.0646 \\
\hline & $(0.000348)$ & $(0.000348)$ & $(0.110)$ & $(0.204)$ & $(0.981)$ & $(0.109)$ \\
\hline \multirow[t]{2}{*}{ inflation } & $-8.85 e-06$ & $-8.85 e-06$ & 0.00218 & 0.00860 & -0.00616 & 0.00320 \\
\hline & (3.83e-05) & (3.83e-05) & $(0.00247)$ & $(0.00525)$ & $(0.0440)$ & $(0.0273)$ \\
\hline \multirow[t]{2}{*}{ Constant } & $0.00479 *$ & $0.00479 *$ & $-0.697^{*}$ & -0.511 & -10.59 & -0.289 \\
\hline & $(0.00244)$ & $(0.00244)$ & $(0.365)$ & $(0.387)$ & $(5.794)$ & $(0.776)$ \\
\hline Observations & 121 & 121 & 511 & 186 & 16 & 378 \\
\hline Number of firms & 43 & 43 & 177 & 80 & 6 & 127 \\
\hline R-squared & 0.260 & 0.260 & 0.086 & 0.096 & 0.971 & 0.054 \\
\hline
\end{tabular}

Standard errors in parentheses; $* * * \mathrm{p}<0.01,{ }^{* *} \mathrm{p}<0.05,{ }^{*} \mathrm{p}<0.1$; all variables are lagged by one year. See note to Table 5 for variable definitions. 
Table A1 (continued). First-stage fixed effects estimates of liability ratio 2001-2005

\begin{tabular}{lcccccc}
\hline & Bulgaria & Croatia & Czech & Hungary & Latvia & Poland \\
$(4)$ & $(2)$ & $(3)$ & $(4)$ & $(5)$ & $(6)$ \\
\hline Log assets & 0.148 & 0.0205 & -0.00129 & $0.496^{* * *}$ & -0.207 & $0.131^{* *}$ \\
& $(0.0956)$ & $(0.0540)$ & $(0.0510)$ & $(0.0920)$ & $(0.247)$ & $(0.0516)$ \\
Asset growth & -0.0257 & -0.0402 & 0.00117 & $-0.161^{* *}$ & 0.0115 & -0.00148 \\
& $(0.0497)$ & $(0.0388)$ & $(0.00201)$ & $(0.0565)$ & $(0.156)$ & $(0.00173)$ \\
age & 0.0363 & 0.0191 & -0.0364 & $-0.142^{* * *}$ & 0.0356 & $-0.0508^{* * *}$ \\
& $(0.0313)$ & $(0.0184)$ & $(0.0246)$ & $(0.0236)$ & $(0.0559)$ & $(0.0185)$ \\
fixed assets & $-0.405^{*}$ & -0.0731 & -0.149 & 0.114 & -0.426 & 0.0596 \\
& $(0.244)$ & $(0.113)$ & $(0.186)$ & $(0.222)$ & $(0.419)$ & $(0.103)$ \\
intangible assets & 0.369 & -1.051 & $-2.969^{* * *}$ & $-10.28^{* * *}$ & $1.261^{* *}$ & 0.440 \\
& $(1.570)$ & $(0.863)$ & $(0.928)$ & $(1.392)$ & $(0.622)$ & $(0.558)$ \\
profitability & $-3.503^{* * *}$ & $0.275^{*}$ & -0.0777 & $-1.675^{* * *}$ & -0.620 & $-0.213^{* * *}$ \\
& $(0.155)$ & $(0.152)$ & $(0.0987)$ & $(0.195)$ & $(1.340)$ & $(0.0814)$ \\
Shareholder’s funds & $0.934^{* * *}$ & $-0.268 * *$ & $1.027 * * *$ & $2.086^{* * *}$ & -0.441 & $0.391^{* * *}$ \\
& $(0.206)$ & $(0.107)$ & $(0.179)$ & $(0.322)$ & $(1.075)$ & $(0.113)$ \\
Industry_median & -0.0607 & -0.0113 & $0.604^{* * *}$ & $2.156^{* * *}$ & -0.279 & 0.125 \\
& $(0.0612)$ & $(0.132)$ & $(0.195)$ & $(0.213)$ & $(0.708)$ & $(0.111)$ \\
inflation & $-0.0287^{* *}$ & -0.0169 & 0.0169 & -0.00286 & 0.000949 & $0.0174 *$ \\
& $(0.0118)$ & $(0.0195)$ & $(0.0170)$ & $(0.00377)$ & $(0.0243)$ & $(0.0101)$ \\
Constant & $-2.323^{* *}$ & -0.690 & 0.596 & $-1.924^{* *}$ & 2.014 & $1.418^{* *}$ \\
& $(1.154)$ & $(0.893)$ & $(0.671)$ & $(0.672)$ & $(2.624)$ & $(0.696)$ \\
Observations & 341 & 250 & 89 & 23 & 32 & 244 \\
Number of firms & 132 & 88 & 33 & 10 & 13 & 101 \\
R-squared & 0.732 & 0.142 & 0.480 & 0.993 & 0.402 & 0.144 \\
\hline
\end{tabular}

Standard errors in parentheses; ${ }^{* * *} \mathrm{p}<0.01,{ }^{* *} \mathrm{p}<0.05,{ }^{*} \mathrm{p}<0$; all variables are lagged by one year. See note to Table 5 for variable definitions. 
Table A1(continued). First-stage fixed effects estimates of liability ratio 2001-2005

\begin{tabular}{|c|c|c|c|c|c|c|}
\hline & $\begin{array}{c}\text { Romania } \\
(7)\end{array}$ & $\begin{array}{c}\text { Russia } \\
(8)\end{array}$ & $\begin{array}{c}\text { Serbia } \\
(9)\end{array}$ & $\begin{array}{c}\text { Slovakia } \\
(10)\end{array}$ & $\begin{array}{c}\text { Slovenia } \\
\text { (11) }\end{array}$ & $\begin{array}{l}\text { Ukraine } \\
\text { (12) }\end{array}$ \\
\hline Log assets & $\begin{array}{l}0.182 * * \\
(0.0756)\end{array}$ & $\begin{array}{c}-0.0199 \\
(0.0133)\end{array}$ & $\begin{array}{l}-0.0166 \\
(0.0383)\end{array}$ & $\begin{array}{c}0.159 * * * \\
(0.0523)\end{array}$ & $\begin{array}{c}0.185 \\
(0.181)\end{array}$ & $\begin{array}{l}-0.0333 \\
(0.0358)\end{array}$ \\
\hline Asset growth & $\begin{array}{l}-0.0688 \\
(0.0438)\end{array}$ & $\begin{array}{c}7.89 \mathrm{e}-05 \\
(6.41 \mathrm{e}-05)\end{array}$ & $\begin{array}{c}0.00952 \\
(0.0265)\end{array}$ & $\begin{array}{c}0.0644 * * \\
(0.0254)\end{array}$ & $\begin{array}{c}0.0338 \\
(0.0835)\end{array}$ & $\begin{array}{l}0.00230 \\
(0.0150)\end{array}$ \\
\hline age & $\begin{array}{l}-0.156 \\
(0.151)\end{array}$ & $\begin{array}{c}-0.00135 \\
(0.0103)\end{array}$ & $\begin{array}{c}0.0731 * * * \\
(0.0128)\end{array}$ & $\begin{array}{l}0.00806 \\
(0.0228)\end{array}$ & $\begin{array}{c}0.0675 \\
(0.0520)\end{array}$ & $\begin{array}{c}0.0100 \\
(0.135)\end{array}$ \\
\hline fixed assets & $\begin{array}{l}-0.122 \\
(0.184)\end{array}$ & $\begin{array}{l}-0.151 \\
(0.134)\end{array}$ & $\begin{array}{c}-0.00113 \\
(0.0757)\end{array}$ & $\begin{array}{c}0.512^{* * *} \\
(0.108)\end{array}$ & $\begin{array}{l}-0.0517 \\
(0.0770)\end{array}$ & $\begin{array}{l}-0.0115 \\
(0.0971)\end{array}$ \\
\hline intangible assets & $\begin{array}{c}2.242 \\
(2.491)\end{array}$ & $\begin{array}{c}0.00283 \\
(1.150)\end{array}$ & $\begin{array}{l}0.0168 \\
(0.198)\end{array}$ & $\begin{array}{c}-0.828^{* *} \\
(0.333)\end{array}$ & $\begin{array}{c}1.426 \\
(1.204)\end{array}$ & $\begin{array}{l}-0.642 \\
(1.236)\end{array}$ \\
\hline profitability & $\begin{array}{c}-0.807 * * * \\
(0.202)\end{array}$ & $\begin{array}{l}0.0274 \\
(0.123)\end{array}$ & $\begin{array}{c}-0.126 \\
(0.0924)\end{array}$ & $\begin{array}{c}-0.353 * * * \\
(0.0963)\end{array}$ & $\begin{array}{c}0.755 \\
(0.545)\end{array}$ & $\begin{array}{c}0.0301 \\
(0.0976)\end{array}$ \\
\hline Shareholder's funds & $\begin{array}{c}0.182 \\
(0.150)\end{array}$ & $\begin{array}{c}0.120^{*} \\
(0.0625)\end{array}$ & $\begin{array}{l}-0.134 * \\
(0.0724)\end{array}$ & $\begin{array}{c}-0.115 \\
(0.0846)\end{array}$ & $\begin{array}{c}0.172 \\
(0.310)\end{array}$ & $\begin{array}{c}-0.309 * * * \\
(0.0832)\end{array}$ \\
\hline Industry_median & $\begin{array}{c}-0.144 \\
(0.160)\end{array}$ & $\begin{array}{c}0.290 * * \\
(0.126)\end{array}$ & $\begin{array}{c}0.122 \\
(0.109)\end{array}$ & $\begin{array}{l}-0.0375 \\
(0.0856)\end{array}$ & $\begin{array}{c}-0.158 \\
(0.176)\end{array}$ & $\begin{array}{r}-0.00537 \\
(0.0876)\end{array}$ \\
\hline inflation & $\begin{array}{c}-0.0358 \\
(0.0511)\end{array}$ & $\begin{array}{l}-0.00959 \\
(0.00621)\end{array}$ & $\begin{array}{c}-0.00714^{* *} \\
(0.00304)\end{array}$ & $\begin{array}{c}0.000667 \\
(0.00614)\end{array}$ & $\begin{array}{c}0.0428 \\
(0.0331)\end{array}$ & $\begin{array}{c}-5.60 \mathrm{e}-05 \\
(0.0323)\end{array}$ \\
\hline Constant & $\begin{array}{c}1.873 \\
(3.255)\end{array}$ & $\begin{array}{c}115.1^{* * *} \\
(0.426)\end{array}$ & $\begin{array}{c}-2.587 * * * \\
(0.449)\end{array}$ & $\begin{array}{l}-1.003^{*} \\
(0.512)\end{array}$ & $\begin{array}{l}-6.455 \\
(3.872)\end{array}$ & $\begin{array}{c}0.906 \\
(0.917)\end{array}$ \\
\hline Observations & 121 & 426 & 511 & 186 & 60 & 378 \\
\hline Number of firms & 43 & 170 & 177 & 80 & 21 & 127 \\
\hline R-squared & 0.267 & 0.054 & 0.265 & 0.620 & 0.474 & 0.105 \\
\hline
\end{tabular}

Standard errors in parentheses; $* * * \mathrm{p}<0.01,{ }^{* *} \mathrm{p}<0.05,{ }^{*} \mathrm{p}<0.1$; all variables are lagged by one year. See note to Table 5 for variable definitions. 
Table A2. Incidence of Excess Leverage in East Asia 1995-2002

\begin{tabular}{ll}
\hline Countries & $\begin{array}{c}\text { \% of firms with excess leverage } \\
\text { i.e., debt ratio }>\text { own optimal debt ratio }\end{array}$ \\
\hline Indonesia & 43.6 \\
Korea & 42.3 \\
Malaysia & 42.5 \\
Thailand & 45 \\
Mean for the worst affected countries & $\mathbf{4 3 . 4}$ \\
Hong Kong & 19.5 \\
Singapore & 21 \\
Taiwan & 24.9 \\
Mean for the least affected countries & $\mathbf{2 1 . 8}$ \\
\hline
\end{tabular}

Source: Driffield and Pal (2010). 
Table A3. Further robustness checks of threshold estimates

Case $1 \quad$ All larger firms All indebted larger

Firm size

firms

All larger firms All indebted larger

firms

Variable

Coefficient t-statistic Coefficien t-statistic Variable Coefficient t-statistic Coefficie t-statistic

\begin{tabular}{|c|c|c|c|c|c|c|c|c|c|}
\hline TDTA+ & -0.0215 & -3.8615 & -0.4616 & -4.6344 & TLTA+ & -0.231 & -2.517 & -0.3242 & -5.6294 \\
\hline TDTA= & 0.0845 & 3.2176 & 0.0874 & 2.7003 & TLTA= & 0.0697 & 1.8198 & 0.0945 & 2.9145 \\
\hline TDTA- & 0.3421 & 1.9773 & 0.2142 & 3.3905 & TLTA- & 0.4495 & 2.3502 & 0.5741 & 4.7187 \\
\hline $\begin{array}{l}95 \% \text { CI to } \\
\text { threshold }\end{array}$ & \multicolumn{2}{|c|}{$0.317-0.334$} & \multicolumn{2}{|c|}{$0.321-0.403$} & $\begin{array}{l}95 \% \text { CI } \\
\text { to } \\
\text { threshold }\end{array}$ & \multicolumn{2}{|c|}{$0.337-0.407$} & \multicolumn{2}{|c|}{$0.361-0.399$} \\
\hline
\end{tabular}

\begin{tabular}{|c|c|c|c|c|c|c|c|c|c|}
\hline \multirow{2}{*}{$\begin{array}{l}\text { Case } 2 \\
\text { Intangibles } \\
\text { Variable }\end{array}$} & \multicolumn{2}{|c|}{$\begin{array}{c}\text { All firms with high } \\
\text { intangibles }\end{array}$} & \multicolumn{2}{|c|}{$\begin{array}{c}\text { All indebted firms } \\
\text { with high } \\
\text { intangibles }\end{array}$} & \multirow[b]{2}{*}{ Variable } & \multicolumn{2}{|c|}{$\begin{array}{c}\text { All firms with high } \\
\text { intangibles }\end{array}$} & \multicolumn{2}{|c|}{$\begin{array}{c}\text { All indebted firms } \\
\text { with high } \\
\text { intangibles }\end{array}$} \\
\hline & Coefficient & t-statistic & $\begin{array}{c}\text { Coefficien } \\
\mathrm{t}\end{array}$ & t-statistic & & Coefficient & t-statistic & $\begin{array}{c}\text { Coefficie } \\
\mathrm{nt}\end{array}$ & t-statistic \\
\hline TDTA+ & -0.0251 & -3.0788 & -0.4531 & -3.71 & TLTA+ & -0.2003 & -2.3491 & -0.2632 & -6.2404 \\
\hline TDTA= & 0.1043 & 2.7073 & 0.0853 & 2.1686 & TLTA= & 0.0631 & 1.8018 & 0.0809 & 2.9414 \\
\hline TDTA- & 0.3586 & 1.5929 & 0.2615 & 3.1402 & TLTA- & 0.3544 & 2.785 & 0.6861 & 4.8787 \\
\hline $\begin{array}{l}\text { 95\% CI to } \\
\text { threshold }\end{array}$ & \multicolumn{2}{|c|}{$0.458-0.504$} & \multicolumn{2}{|c|}{$0.364-0.447$} & $\begin{array}{l}95 \% \text { CI } \\
\text { to } \\
\text { threshold }\end{array}$ & \multicolumn{2}{|c|}{$0.401-0.442$} & \multicolumn{2}{|c|}{$0.392-0.426$} \\
\hline
\end{tabular}

Note. TDTA refers to debt ratio while TLTA refers to liability ratio. TDTA+, TLTA+ refer to values of leverage in excess of the upper threshold; TDTA=, TLTA= refer to the values of leverage between the upper and lower threshold while TDTA-, TLTA- refer to the values of leverage below the lower threshold. CI refers to confidence interval. Other control variables are same as in Table 7. 


\section{Appendix 2}

\section{Calculation of TFP}

The approach and methodology are well developed and adopted from the existing literature (see e.g., Griffith 1999). This essentially involves estimating the following basic production function:

$$
y_{i v}=\alpha_{k} k_{i v}+\alpha_{i} l_{t e}+\alpha_{m} m_{i v}+\varepsilon_{i s}
$$

where subscripts $i, t$ refer to firm and year; $y_{i t}, k_{i}, l_{i t}$, and $m_{i t}$ represent the logarithm of a firm's output (sales) and the production inputs: capital (measured as the book value of fixed assets), labour (number of employees) and material costs respectively. We estimate $\varepsilon_{i t}$ from (1) as TFP and then determine the $\log ($ TFP). To deflate monetary values we use the appropriate producer price index for each manufacturing industry and consumer price index for services available from EU-KLMS (Gottingen) and also WWII (Vienna).

One of the most common econometric problems with the estimation of TFP concerns endogeneity, when regressors and the error terms become correlated. This is because at least a part of the TFP will be observed by the firm at a time early enough so as to allow the firm to change the factor input decision. If that is the case, then profit maximization implies that the realisation of the error term is expected to influence the decision on factor inputs. Consequently the OLS estimates could turn out to be inconsistent. As an alternative we use Levinsohn-Petrin correction, who extend Olley and Pakes (1996) approach by using material inputs as a proxy to control for unobservable productivity shocks, as it is more common for firms to register material costs every year. Accordingly, we generate two series TFP and TFP_LP using the standard and Levinsohn-Petrin methods respectively, although TFP_LP remains our preferred measure. 